\title{
Comparison of Fast In situ Stratospheric Hygrometer (FISH) measurements of water vapor in the upper troposphere and lower stratosphere (UTLS) with ECMWF (re)analysis data
}

\author{
A. Kunz ${ }^{1}$, N. Spelten ${ }^{2}$, P. Konopka ${ }^{2}$, R. Müller ${ }^{2}$, R. M. Forbes ${ }^{3}$, and H. Wernli ${ }^{1}$ \\ ${ }^{1}$ Institute for Atmospheric and Climate Research, ETH Zurich, Zurich, Switzerland \\ ${ }^{2}$ Institut für Energie- und Klimaforschung: Stratosphäre (IEK-7), Forschungszentrum Jülich, Jülich, Germany \\ ${ }^{3}$ European Centre for Medium-Range Weather Forecasts, Reading, UK
}

Correspondence to: A. Kunz (anne.kunz@env.ethz.ch)

Received: 2 April 2014 - Published in Atmos. Chem. Phys. Discuss.: 3 June 2014

Revised: 9 September 2014 - Accepted: 12 September 2014 - Published: 14 October 2014

\begin{abstract}
An evaluation of water vapor in the upper troposphere and lower stratosphere (UTLS) of the ERA-Interim, the global atmospheric reanalysis produced by the European Centre for Medium-Range Weather Forecasts (ECMWF), is presented. Water vapor measurements are derived from the Fast In situ Stratospheric Hygrometer (FISH) during a large set of airborne measurement campaigns from 2001 to 2011 in the tropics, midlatitudes and polar regions, covering isentropic layers from 300 to $400 \mathrm{~K}(5-18 \mathrm{~km})$.

The comparison shows around $87 \%$ of the reanalysis data are within a factor of 2 of the FISH water vapor measurements and around $30 \%$ have a nearly perfect agreement with an over- and underestimation lower than $10 \%$. Nevertheless, strong over- and underestimations can occur both in the UT and LS, in particularly in the extratropical LS and in the tropical UT, where severe over- and underestimations up to 10 times can occur.

The analysis data from the evolving ECMWF operational system is also evaluated, and the FISH measurements are divided into time periods representing different cycles of the Integrated Forecast System (IFS). The agreement with FISH improves over the time, in particular when comparing water vapor fields for time periods before 2004 and after 2010. It appears that influences of tropical tropospheric and extratropical UTLS processes, e.g., convective and quasiisentropic exchange processes, are particularly challenging for the simulation of the UTLS water vapor distribution. Both the reanalysis and operational analysis data show the tendency of an overestimation of low water vapor mixing ra-
\end{abstract}

tio ( $\lesssim 10 \mathrm{ppmv}$ ) in the LS and underestimation of high water vapor mixing ratio ( $\gtrsim 300 \mathrm{ppmv})$ in the UT.

\section{Introduction}

Water vapor is one of the most important greenhouse gases in the atmosphere and plays a key role in the atmospheric part of the climate system. A change in water vapor, in particular in the upper troposphere and lower stratosphere (UTLS), affects the surface climate and is important for understanding the decadal variability of surface temperatures (Forster and Shine, 1997; Solomon et al., 2010; Riese et al., 2012).

Water vapor is an extremely variable trace gas that is affected by phase transitions from and to liquid and solid hydrometeors. In the UTLS, the formation and sublimation of ice particles in cirrus clouds is particularly relevant. Water vapor is also involved in atmospheric chemistry. In the troposphere it is the prime source of hydroxyl radicals (e.g., Rohrer and Berresheim, 2006), and thus water vapor indirectly controls the lifetime of most gaseous atmospheric pollutants in the atmosphere. In the stratosphere water vapor may be chemically produced through the oxidation of methane (Jones and Pyle, 1984; Röckmann et al., 2004; Rohs et al., 2006). Transport processes in the troposphere play a key role for the distribution of water vapor. In the vicinity of the tropopause and in particular across the subtropical jet stream, large gradients of water vapor exist due to the barrier effects of the tropopause (Haynes and Shuckburgh, 2000; 
Pan et al., 2004; Flentje et al., 2007; Kunz et al., 2011b). In the tropics, the low temperatures at the tropopause lead to strong freeze-drying (Jensen and Pfister, 2004; Fueglistaler et al., 2009; Schiller et al., 2009).

The representation of these UTLS processes is challenging for operational numerical weather prediction (NWP) models, and the NWP system from the European Centre for MediumRange Weather Forecasts (ECMWF) is evaluated here. Besides the operational analysis and forecast cycles, ECMWF has produced different global atmospheric reanalysis products, e.g., ERA-40 from 1957 to 2002 (Uppala et al., 2006) and ERA-Interim covering the time period from 1979 to present (Dee et al., 2011).

Validation studies of the ECMWF water vapor fields show that the operational analysis and forecasted UTLS water vapor fields might in some cases deviate significantly from independent in situ observations (Flentje et al., 2007; Schäfler et al., 2010). Flentje et al. (2007) evaluated the short-term high-resolution ECMWF forecasts by airborne lidar water vapor measurements during the international TROCCINOX (Tropical Convection, Cirrus and Nitrogen Oxides Experiment) campaign. Based on a case study for March 2004 above the tropical and subtropical Atlantic between Brazil and Europe, Flentje et al. (2007) found an overall good reproduction of the observed water vapor distribution. However, locally there were large differences in the vicinity of strong water vapor gradients, a too-moist and shallow boundary layer, and an overestimation of convective transport of moisture to the UT. Schäfler et al. (2010) presented a similar case study for operational ECMWF analyses based on measurements during a campaign over western Europe in August 2007. Their comparison of lidar water vapor measurements with ECMWF analyses revealed an overestimation of boundary layer moisture in localized regions over Europe.

A more climatological evaluation of water vapor fields based on the multiyear MOZAIC (Measurements of Ozone and Water Vapour by Airbus In-Service Aircraft) program was presented for the former ERA-40 data set by Oikonomou and O'Neill (2006) and for operational ECMWF analysis fields by Luo et al. (2007). Oikonomou and O'Neill (2006) found for 1991 to 1999 that the ERA-40 mixing ratios of water vapor are considerably larger than observed by MOZAIC, typically by $20 \%$ in the tropical upper troposphere, and by more than $60 \%$ in the lower stratosphere at high latitudes. The moist bias with an overestimation of the extratropical lower stratospheric specific humidity in the ECMWF operational analysis and forecast system has been also intensively studied with CARIBIC (Civil Aircraft for the Regular Investigation of the atmosphere Based on an Instrument Container) in situ measurements between 2005 and 2012 (Dyroff et al., 2014).

A moist model bias in the extratropical lowermost stratosphere has the potential to impact the temperature distribution, including a cold bias near the tropopause (Stenke et al., 2008). It is thus important to improve the moist bias in atmo- spheric models for the calculation of radiative fluxes, particularly in the stratosphere, where absolute humidities are small but relative errors can be large. The moist model bias analyzed with the MOZAIC measurements may be due to limitations in the ECMWF model, as described by Oikonomou and O'Neill (2006). The exact difference between the model and MOZAIC measurements may also be influenced by the bias in the MOZAIC water vapor observations in the lower stratosphere. The MOZAIC relative humidity sensor likely has a positive bias above the tropopause compared to highresolution observations with the Fast In situ Stratospheric Hygrometer (FISH) (Kunz et al., 2008).

The ERA-Interim water vapor data set has already been used for studies of key atmospheric processes in the UTLS such as the Brewer-Dobson circulation and the double tropopause (Castanheira et al., 2012), or the transport of water vapor from the subtropics toward the extratropics (Ploeger et al., 2013). A detailed evaluation of the ERA-Interim representation of water vapor does not exist and is therefore the main aim of this study. An assessment of the quality of the ERA-Interim water vapor product is particularly relevant for further improving the hydrological cycle in the ECMWF model and for a better understanding and interpretation of diagnostic studies using water vapor fields of this comprehensive data set.

In the following, all available high-resolution in situ water vapor measurements by the FISH instrument from 2001 to 2011 are used for a comprehensive validation of ERAInterim water vapor in the UTLS. FISH has successfully participated in a large number of airborne measurement campaigns both in the Northern and Southern Hemisphere during recent years. Data from different measurement campaigns are obtained in polar regions (EUPLEX2003, POLARCAT2008, RECONCILE2010), at midlatitudes (SPURT2001-2003, ENVISAT2002, EUPLEX2003, CIRRUS2003-2006, MACPEX2011) and in the tropics (TROCCINOX2005, SCOUT2005, AMMA2006). Taking the water vapor data of all these measurement campaigns therefore results in a comprehensive data set, referred to here as the FISH-based water vapor climatology, at altitudes from 5 to $18 \mathrm{~km}$, i.e., covering the UTLS. Thus, the FISH-based water vapor climatology is well suited for an evaluation of the global distribution of ERA-Interim water vapor fields in the UTLS. Since the reanalysis product is based on a single fixed version of data assimilation and forecast model, the ECMWF operational analyses are also considered for the time period of the FISH-based water vapor climatology to study the changes of the UTLS water vapor simulation from changes in the operational forecasting system from 2001 to 2011.

A one-to-one comparison of measured and modeled water vapor fields will lead to (1) a quantification of the agreement between observed and reanalyzed water vapor for specified episodes, and (2) an investigation of the change of the water vapor representation in operational ECMWF analyses. The 
paper is structured as follows. In Sect. 2 the database will be described. The FISH measurements, the ERA-Interim and the operational analysis data sets will be introduced and the methodology to compare observations and (re)analyses will be described. The results will be presented in Sect. 3 and finally summarized and discussed in Sect. 4.

\section{Data description and analysis methodology}

\subsection{FISH measurements}

\subsubsection{Measurement technique of FISH}

$\mathrm{H}_{2} \mathrm{O}$ mixing ratio is measured in situ using the FISH instrument (Zöger et al., 1999), which is based on the Lyman $\alpha$ photo-fragment fluorescence technique. The FISH instrument has been flown on a variety of airborne platforms. It has a forward-facing inlet and measures total water, i.e., the sum of the gaseous and the condensed phase. FISH is regularly calibrated in the laboratory against a commercial frostpoint hygrometer. The response time is $1 \mathrm{~s}$, which allows also the detection of small-scale variations of the $\mathrm{H}_{2} \mathrm{O}$ mixing ratio in the vicinity of the tropopause, in clouds and contrails. The instruments accuracy is $7 \%$ and the detection limit is better than 0.3 ppmv. The FISH instrument is therefore particularly suitable for water vapor measurements in the stratosphere, where other instruments such as the MOZAIC sensors lose their sensitivity, resulting in a moist bias of MOZAIC data compared to FISH measurements in the extratropical LS (Kunz et al., 2008). In all aircraft campaigns the FISH instrument is switched on above a pressure level of roughly $400 \mathrm{hPa}$. The boundary layer is therefore not captured by the FISH measurements. In the lower troposphere, the measurement cell of FISH becomes optically dense due to large mixing ratios and the FISH fluorescence method is limited on in situ measurements above a mixing ratio of 500 ppmv. Critical FISH measurements above $500 \mathrm{ppmv}(\gtrsim 400 \mathrm{hPa})$ are therefore excluded from this analysis, following Kunz et al. (2008).

\subsubsection{FISH-based water vapor climatology}

For this study we use the data of 10 international measurement campaigns with different scientific objectives (see Table 1 for an overview). Polar campaigns such as RECONCILE2010 were aimed at a better understanding of polar vortex dynamics and chemical reactions (von Hobe et al., 2013). Other campaigns, such as the eight SPURT campaigns over 2 years, were intended to observe seasonal differences of various trace gases in the midlatitude tropopause region (Engel et al., 2006), and tropical campaigns such as TROCCINOX2005 investigated the impact of tropical deep convection on the distribution and the sources of trace gases, cloud and aerosol particles in the UTLS (Flentje et al., 2007; Schiller et al., 2009).
The resulting FISH-based water vapor climatology extends from 2001 to 2011 . It consists of measurements from 148 flights on 136 different days, corresponding to more than $600 \mathrm{~h}$ with FISH water vapor data in the UTLS. In this study, only the gas-phase water vapor is used; i.e., water vapor mixing ratios are selected which are lower than the saturation mixing ratio, corresponding to a relative humidity with respect to ice of $100 \%$. In contrast to the Northern Hemisphere airborne in situ climatology by Tilmes et al. (2010) from 1995 to 2008, only FISH measurements will be considered here, leading to a more homogeneous observational data set based on the same measurement technique. Thus, the FISHbased water vapor climatology proves to be well suited for a model evaluation since the results are not influenced by changing measurement accuracies or height-dependent sensitivities of the measurement instrument (Kunz et al., 2008).

Figure 1a shows the geographical distribution of all measurements included in the FISH-based water vapor climatology. Most of the flights were performed over Europe spanning a region from $30^{\circ}$ to $80^{\circ} \mathrm{N}$ and $10^{\circ} \mathrm{W}$ to $30^{\circ} \mathrm{E}$. In the Northern Hemisphere, the data set also contains measurements over Greenland obtained in 2008, over the US sampled in 2011 and over Africa in 2006. In the Southern Hemisphere, the FISH-based water vapor climatology contains measurements over Brazil and Australia in the year 2005.

The highest frequency of measurements is in the vicinity of the tropopause (Fig. 1b), roughly around 16 to $18 \mathrm{~km}$ in the tropics and around 9 to $12 \mathrm{~km}$ in the midlatitudes poleward of the subtropical jet stream. In the Arctic, there is also a high frequency of measurements in the deeper stratosphere at around $18 \mathrm{~km}$ from campaigns with polar-vortex-related objectives, such as RECONCILE2010. There is also a high measurement frequency in the middle troposphere at around $5 \mathrm{~km}$ from POLARCAT2008.

\subsection{ERA-Interim data}

The specific humidity from the ERA-Interim reanalysis data set from the ECMWF (Dee et al., 2011) is evaluated in this paper. The model configuration is based on 60 model hybrid levels with the top of the atmosphere located at $0.1 \mathrm{hPa}$ and a spectral T255 horizontal resolution. ERA-Interim is based on Integrated Forecast System (IFS) release Cy31r2, taken for operational forecasting at ECMWF from 12 December 2006 until 5 June 2007. Dee et al. (2011) gives a comprehensive overview of the ERA-Interim data set, including the data assimilation methodology, the forecast model and the input observations. Although the observational network changes over time, the reanalysis product is based on a single fixed version of data assimilation and forecast model, in contrast to the changing operational forecasting system. For this study, ERA-Interim data on a $1^{\circ} \times 1^{\circ}$ horizontal grid are used for the 136 days of measurement flights (Table 1 and Fig. 1). The data are then processed as follows: 
Table 1. Information on campaigns of the FISH-based water vapor climatology, including both local and transfer flights. The number of missions refers to the flight missions used for this climatology; i.e., the total amount of flight missions per campaign may be higher. The approximate regional extent of the 148 flight missions is shown in Fig. 1.

\begin{tabular}{|c|c|c|c|c|c|}
\hline Campaign & Time & Location & Flight missions & Flight hours & Campaign objectives \\
\hline $\begin{array}{l}\text { SPURT } \\
\text { (Trace gas transport } \\
\text { in the tropopause region) } \\
\text { e.g., Engel et al. (2006) }\end{array}$ & $\begin{array}{l}\text { Nov 2001, Jan } 2002 \\
\text { May 2002, Aug } 2002 \\
\text { Oct 2002, Feb } 2003 \\
\text { Apr 2003, Jul } 2003\end{array}$ & $\begin{array}{l}\text { Hohn } \\
\text { (Germany) }\end{array}$ & 34 & $\approx 147$ & $\begin{array}{l}\text { UTLS trace gas climatology } \\
\text { Atmospheric transport and } \\
\text { seasonal variation of trace gases }\end{array}$ \\
\hline $\begin{array}{l}\text { EUPLEX } \\
\text { (European Polar Stratospheric Cloud } \\
\text { and Lee Wave Experiment) }\end{array}$ & Jan 2003, Feb 2003 & $\begin{array}{l}\text { Kiruna } \\
\text { (Sweden) }\end{array}$ & 7 & $\approx 40$ & $\begin{array}{l}\text { Polar stratospheric clouds } \\
\text { Ozone loss in polar vortex } \\
\text { Chlorine activation } \\
\text { De- and renitrification }\end{array}$ \\
\hline $\begin{array}{l}\text { POLARCAT GRACE } \\
\text { (Greenland Aerosol } \\
\text { and Chemistry Experiment) } \\
\text { www.pa.op.dlr.de/polarcat/ }\end{array}$ & Jul 2008 & $\begin{array}{l}\text { Kangerlussuaq } \\
\text { (Greenland) }\end{array}$ & 13 & $\approx 80$ & $\begin{array}{l}\text { Boreal forest fire emissions } \\
\text { into the UTLS } \\
\text { Annual variation of trace gases } \\
\text { and aerosols in the Arctic }\end{array}$ \\
\hline $\begin{array}{l}\text { RECONCILE } \\
\text { (Reconciliation of essential process } \\
\text { parameters for an enhanced } \\
\text { predictability of Arctic strat. ozone } \\
\text { loss and its climate interactions) } \\
\text { e.g., von Hobe et al. (2013) }\end{array}$ & $\begin{array}{l}\text { Jan 2010, Feb } 2010 \\
\text { Mar } 2010\end{array}$ & $\begin{array}{l}\text { Kiruna } \\
\text { (Sweden) }\end{array}$ & 13 & $\approx 52$ & $\begin{array}{l}\text { Polar vortex chemical reactions } \\
\text { Catalytic CLOx/BrOx chemistry } \\
\text { Chlorine activation on PSCs } \\
\text { NAT nucleation mechanisms }\end{array}$ \\
\hline \multirow[t]{2}{*}{$\begin{array}{l}\text { ENVISAT } \\
\text { e.g., Blom et al. (2003) }\end{array}$} & Jun 2002, Oct 2002 & $\begin{array}{l}\text { Forli } \\
\text { (Italy) } \\
\&\end{array}$ & 10 & $\approx 44$ & $\begin{array}{l}\text { Validation of ENVISAT chemistry } \\
\text { instruments at midlatitudes }\end{array}$ \\
\hline & Mar 2003 & $\begin{array}{l}\text { Kiruna } \\
\text { (Sweden) }\end{array}$ & 5 & $\approx 20$ & ENVISAT validation in the Arctic \\
\hline $\begin{array}{l}\text { CIRRUS } \\
\text { e.g., Schiller et al. (2008), } \\
\text { Krämer et al. (2009) }\end{array}$ & $\begin{array}{l}\text { Dec } 2003 \text {, Nov } 2004 \\
\text { Nov } 2006\end{array}$ & $\begin{array}{l}\text { Hohn } \\
\text { (Germany) }\end{array}$ & 12 & $\approx 52$ & $\begin{array}{l}\text { Cirrus formation mechanism and } \\
\text { radiative effects } \\
\text { Chemical and microphysical } \\
\text { properties of cloud particles }\end{array}$ \\
\hline $\begin{array}{l}\text { MACPEX } \\
\text { (Midlatitude Airborne Cirrus } \\
\text { Properties Experiment) } \\
\text { www.espo.nasa.gov/macpex/ } \\
\text { e.g., Luebke et al. (2013) }\end{array}$ & Apr 2011 & $\begin{array}{l}\text { Houston } \\
\text { (USA,TX) }\end{array}$ & 15 & $\approx 100$ & $\begin{array}{l}\text { Cirrus formation mechanism } \\
\mathrm{H}_{2} \mathrm{O} \text { instrumental intercomparison }\end{array}$ \\
\hline $\begin{array}{l}\text { TROCCINOX } \\
\text { (Tropical Convection, Cirrus } \\
\text { and Nitrogen Oxides Experiment) } \\
\text { www.pa.op.dlr.de/troccinox }\end{array}$ & Jan 2005, Feb 2005 & $\begin{array}{l}\text { Aracatuba } \\
\text { (Brazil) }\end{array}$ & 14 & $\approx 64$ & $\begin{array}{l}\text { Impact of tropical convection } \\
\text { on UTLS trace gases and particles } \\
\text { Lightning-produced } \mathrm{NO}_{\mathrm{X}} \text { in } \\
\text { tropical thunderstorms }\end{array}$ \\
\hline $\begin{array}{l}\text { SCOUT } \\
\text { (Stratospheric-Climate Links with } \\
\text { Emphasis on the Upper Troposphere } \\
\text { and Lower Stratosphere) } \\
\text { e.g., Vaughan et al. (2008) }\end{array}$ & Nov 2005, Dec 2005 & $\begin{array}{l}\text { Darwin } \\
\text { (Australia) }\end{array}$ & 16 & $\approx 88$ & $\begin{array}{l}\text { Deep tropical convection } \\
\text { Composition of the tropical } \\
\text { transition layer } \\
\text { Transport of trace gases into } \\
\text { the tropical UTLS }\end{array}$ \\
\hline $\begin{array}{l}\text { AMMA } \\
\text { (African Monsoon } \\
\text { Multidisciplinary Analysis) } \\
\text { e.g., Cairo et al. (2010) }\end{array}$ & Jul 2006, Aug 2006 & $\begin{array}{l}\text { Ouagadougou } \\
\text { (Burkina Faso) }\end{array}$ & 9 & $\approx 40$ & $\begin{array}{l}\text { Intense mesoscale convection } \\
\text { connected with African monsoon } \\
\text { Large-scale transport into the UTLS } \\
\text { Lightning and } \mathrm{NO}_{\mathrm{x}} \text { production }\end{array}$ \\
\hline
\end{tabular}

1. ERA-Interim specific humidity fields are interpolated to the positions (latitude, longitude, altitude) of the FISH measurements. For this purpose, 3-D backward and forward trajectories are calculated with the trajectory module of the Chemical Lagrangian Model of the Stratosphere based on a hybrid vertical coordinate system (see McKenna et al. (2002) and Ploeger et al. (2013) for more information on the model and trajectory calculations). These trajectories are initialized at every measurement time and position. After reaching the closest analysis time - i.e., 00:00, 06:00, 12:00 or 18:00 UTC - the respective latitude and longitude positions of the trajectories are stored. At these positions, vertical interpolation of the ERA-Interim specific humidity field is then performed linearly in potential temperature coordinates. Nonlinearity of transport driven by the ERAInterim wind fields is taken into account. It is thus assumed that during this short advection along the trajectories, i.e., smaller than $3 \mathrm{~h}$, the specific humidity does not change. The ERA-Interim specific humidity 

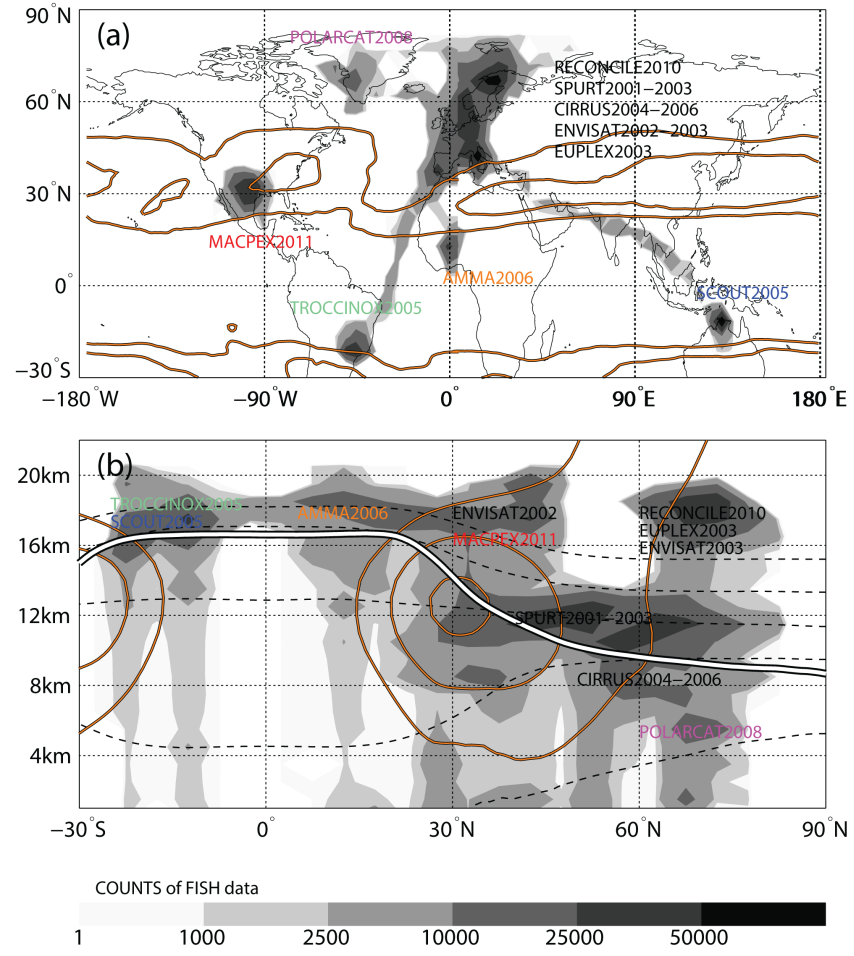

Figure 1. Latitude-longitude (a) and altitude-latitude (b) representation of FISH water vapor measurements. Counts of $1 \mathrm{~Hz}$ measurements are shown for $5^{\circ}$ lat $\times 5^{\circ}$ lon and $1 \mathrm{~km} \times 5^{\circ}$ lat bins, respectively. The measurement locations of the different campaigns are indicated in both panels. The ERA-Interim horizontal wind speed (20 and $30 \mathrm{~m} \mathrm{~s}^{-1}$ ) at $13 \mathrm{~km}$ (a) and the zonal wind speed (10, 20, $30,40 \mathrm{~m} \mathrm{~s}^{-1}$ ) as a cross section through all altitudes (b) are shown as the mean over all 136 flight mission days between 2001 and 2011. The mean ERA-Interim isentropic surfaces (290, 320, 350, $380,410 \mathrm{~K})$ are black dashed lines, and the mean location of the thermal tropopause is depicted by a white solid line.

values (in $\mathrm{kg} \mathrm{kg}^{-1}$ ) are converted to water vapor volume mixing ratio (in ppmv) by multiplication with the quotient of molar masses of dry air and water, i.e., $28.9644 / 18.015 \times 10^{6}$.

2. ERA-Interim meteorological fields - i.e., zonal wind, meridional wind, temperature and geopotential height - are vertically interpolated on isentropic surfaces between 280 and $500 \mathrm{~K}$ (every $10 \mathrm{~K}$ ). Afterward, the isentropic static stability and the potential vorticity (PV) fields are calculated. The PV values are then transformed into equivalent latitudes. For that purpose, on each isentrope the area enclosed by a PV contour in a hemisphere is transformed to a circle with the same area centered at the pole. The equivalent latitude is the distance in degrees of latitude from the Equator to this circle. Afterward, the dynamic tropopause based on the maximum product of $\mathrm{PV}$ gradients and wind speed with equivalent latitude is determined on the different isentropes, following Kunz et al. (2011a). The quasihorizontal distance of the measurement location from the dynamic tropopause is calculated as the isentropic difference of the equivalent latitude of the measurement location and the equivalent latitude of the dynamic tropopause along each geographical longitude, following Kunz et al. (2011b).

3. ERA-Interim temperature fields are extracted in the entire vertical column of the measurement positions. According to WMO (1957) the location of the thermal tropopause based on the vertical lapse rate is determined and the vertical distance of the measurement location from the thermal tropopause is calculated at altitude levels.

\subsection{Operational analysis data}

The same procedure as for the ERA-Interim data in Sect. 2.2 is performed for the specific humidity data from the ECMWF operational analysis. From 2001 to 2006 the data are at a resolution of T511L61 (T511 spectral resolution, 61 levels in the vertical). In 2006, the model horizontal and vertical resolution was increased to T799L91 and then to T1279 at the beginning of January 2010. Thus, the horizontal resolution of the operational analysis data is higher than the fixed T255 resolution of ERA-Interim. For comparison reasons, the operational data are also interpolated to a regular $1^{\circ} \times 1^{\circ}$ horizontal grid. From 2001 to 2011 there have been multiple model changes from IFS Cycle 23r4 in June 2001 (also used for the former reanalysis product ERA-40) to Cycle $37 \mathrm{r} 3$ in November 2011 (see Sect. 2.4 for model changes relevant to the humidity during this period). The comparison of the operational analysis water vapor with the FISH observations will therefore be performed on a daily basis (see Sect. 4). For the evaluation of the temporal change in water vapor representation in operational ECMWF analyses two time intervals representing almost 2 years each are investigated: time interval 1 (Cy28r1-Cy30r1) from March 2004 to August 2006 and time interval 2 (Cy36r1-Cy36r4) from January 2010 to April 2011. These intervals are chosen since they are well represented by the FISH measurements, and a comparison will further show the change in water vapor representation before and after the IFS release $\mathrm{Cy} 31 \mathrm{r} 2$ that is used for ERAInterim.

\subsection{Changes to the IFS over time}

During the period 2001 to 2011 considered here, there have been a number of changes to the IFS that potentially affect the humidity field and representation of the hydrological cycle. The most significant changes are briefly described here although not all humidity impacts have been documented. 
In Cycle 26r3 (2003) a new humidity analysis scheme was implemented (Hólm, 2002) with a nonlinear transformation of the humidity control variable to render the humidity background errors more nearly Gaussian. The modifications to the formulation of the humidity analysis and its impact on the assimilation of humidity-sensitive observations are described by Andersson et al. (2005).

In Cycle 31r1 (2006) just before the ERA-Interim cycle, a revised cloud scheme was introduced including a new parameterization of supersaturation with respect to ice for temperatures lower than $250 \mathrm{~K}$ in the cloud-free part of the grid box (Tompkins et al., 2007). The introduction of ice supersaturation delayed the formation of ice clouds, and the upper-tropospheric humidity increased in the forecast model (Tompkins et al., 2007). However, the degree of ice supersaturation was limited in the four-dimensional variational assimilation (4DVAR) scheme, leading to a spin-up of humidity from the analysis into the forecast (Lamquin et al., 2009).

Cycle 32r3 (2007) included revisions to the free tropospheric diffusion and to the convection scheme, in particular the introduction of a variable convective adjustment timescale and a convective entrainment rate proportional to the environmental relative humidity (Bechtold et al., 2008). This cycle resulted in a significantly higher and more realistic level of model activity in terms of the amplitude of tropical and extratropical mesoscale, synoptic and planetary perturbations with impacts on the UTLS temperature and humidity. This cycle also included a new bias-correction scheme for radiosonde temperature and humidity data as a function of solar elevation and radiosonde type.

In Cycle 35r3 (2009), ice supersaturation was allowed fully in the 4DVAR analysis, leading to an increase in uppertropospheric humidity in the analysis. Finally, Cycle 36r4 (2010) introduced a new cloud scheme with separate prognostic variables for ice cloud, liquid cloud, rain and snow (Forbes et al., 2011) and resulted in some drying of the uppertropospheric humidity into the forecast. Note that in the IFS analysis system no humidity increments are allowed in the stratosphere, which means the distribution of humidity is determined primarily in the forecast model by tropospheric exchange, by upper-level moistening due to methane oxidation and by advection.

\subsection{Ratio of water vapor between (re)analysis fields and FISH}

The ratio between the ECMWF water vapor, e.g., the reanalysis water vapor $\mathrm{H}_{2} \mathrm{O}_{\text {ERA }}$, and the measured FISH water vapor, $\mathrm{H}_{2} \mathrm{O}_{\text {FISH }}$, is calculated as follows:

$\Delta \mathrm{H}_{2} \mathrm{O}_{\text {ERA }}=\mathrm{H}_{2} \mathrm{O}_{\text {ERA }} / \mathrm{H}_{2} \mathrm{O}_{\text {FISH }}$.

A value of $\Delta \mathrm{H}_{2} \mathrm{O}_{\text {ERA }}=1$ indicates a perfect agreement between ERA-Interim and FISH water vapor mixing ratio. The ratio $\Delta \mathrm{H}_{2} \mathrm{O}_{\text {ERA }}$ is an asymmetric quantity; i.e., underestimations are related to $\Delta \mathrm{H}_{2} \mathrm{O} \in[0,1]$ and overestimations

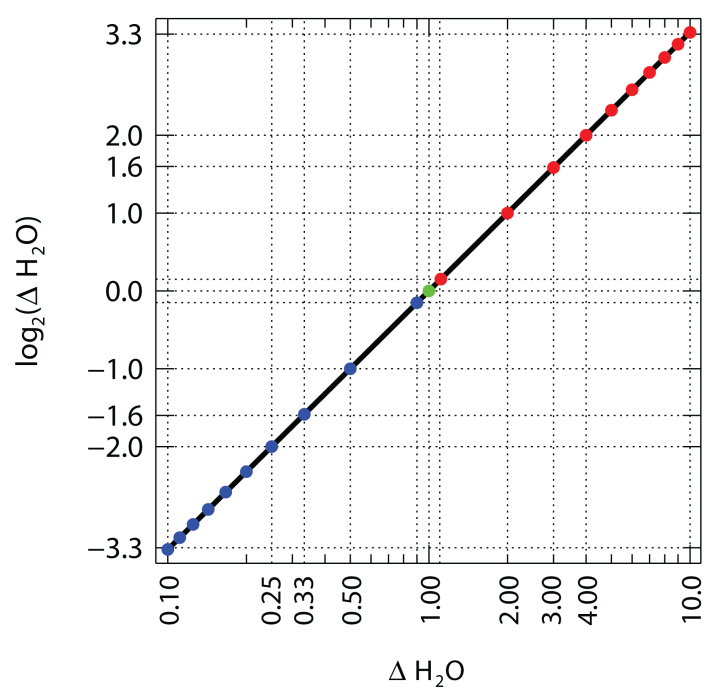

Figure 2. Relationship between the asymmetric quantity $\Delta \mathrm{H}_{2} \mathrm{O}$ and the symmetric quantity $\Delta \mathrm{H}_{2} \mathrm{O}^{\log 2}$ (black line), which is used for the evaluation of simulated and observed water vapor fields. Overestimations $\left(\Delta \mathrm{H}_{2} \mathrm{O}^{\log 2}>0\right)$ are indicated by red dots, underestimations $\left(\Delta \mathrm{H}_{2} \mathrm{O}^{\log 2}<0\right)$ by blue dots and a perfect relationship $\left(\Delta \mathrm{H}_{2} \mathrm{O}^{\log 2}=0\right)$ by the green dot. The values presented are the most relevant ones used in the investigation. In particular, $\Delta \mathrm{H}_{2} \mathrm{O}^{\log 2}$ values of $1,1.6,2,2.3,2.6,2.8,3.0,3.2$, and 3.3 correspond to a model water vapor that is $2,3,4,5,6,7,8,9$ and 10 times larger than the observed water vapor.

to $\Delta \mathrm{H}_{2} \mathrm{O} \in[1, \infty]$. This asymmetry has influences on statistical quantities like mean values. Therefore, the detailed analysis of modeled and observed water vapor is based on the logarithm of $\Delta \mathrm{H}_{2} \mathrm{O}_{\mathrm{ERA}}$ with base 2, i.e.,

$\Delta \mathrm{H}_{2} \mathrm{O}^{\log 2}$ ERA $=\log _{2}\left(\Delta \mathrm{H}_{2} \mathrm{O}_{\text {ERA }}\right)$.

A perfect agreement between the model and observations is now indicated by $\Delta \mathrm{H}_{2} \mathrm{O}_{\mathrm{ERA}}^{\log 2}=0$, underestimations are given by $\Delta \mathrm{H}_{2} \mathrm{O}_{\mathrm{ERA}}^{\log 2} \in[-\infty, 0]$ and overestimations are given by $\Delta \mathrm{H}_{2} \mathrm{O}_{\mathrm{ERA}}^{\log 2} \in[0, \infty]$. Equation (2) is also applied to the operational analysis water vapor $\mathrm{H}_{2} \mathrm{O}_{\mathrm{ANA}}$, and the correspondent ratio is referred to as $\Delta \mathrm{H}_{2} \mathrm{O}_{\mathrm{ANA}}^{\text {log2 }}$. Figure 2 presents the relationship between Eq. (1) and (2) based on the most relevant values for this paper. In particular, $\Delta \mathrm{H}_{2} \mathrm{O}^{\log 2}$ values of $1,1.6,2$, and 3.32 correspond to a model water vapor mixing ratio that is 2, 3, 4 and 10 times larger than the observed water vapor mixing ratio.

The influence of the FISH measurement uncertainty on the ratio $\Delta \mathrm{H}_{2} \mathrm{O}^{\log 2}$ is lower than $22 \%$. According to Sect.2.1.1 we assume an instrument accuracy of $7 \%$ and a detection limit of $0.3 \mathrm{ppmv}$ for the two water vapor mixing ratios $\mathrm{H}_{2} \mathrm{O}_{\text {FISH }}=4$ ppmv and $\mathrm{H}_{2} \mathrm{O}_{\text {FISH }}=100$ ppmv. An overestimation of these water vapor mixing ratios of $\Delta \mathrm{H}_{2} \mathrm{O}^{\log 2}=1$ is therefore connected with an uncertainty range between 0.80 and 1.22 for $\mathrm{H}_{2} \mathrm{O}_{\text {FISH }}=4 \pm 0.58$ ppmv and with an uncertainty range between 0.89 and 1.11 for $\mathrm{H}_{2} \mathrm{O}_{\mathrm{FISH}}=$ 


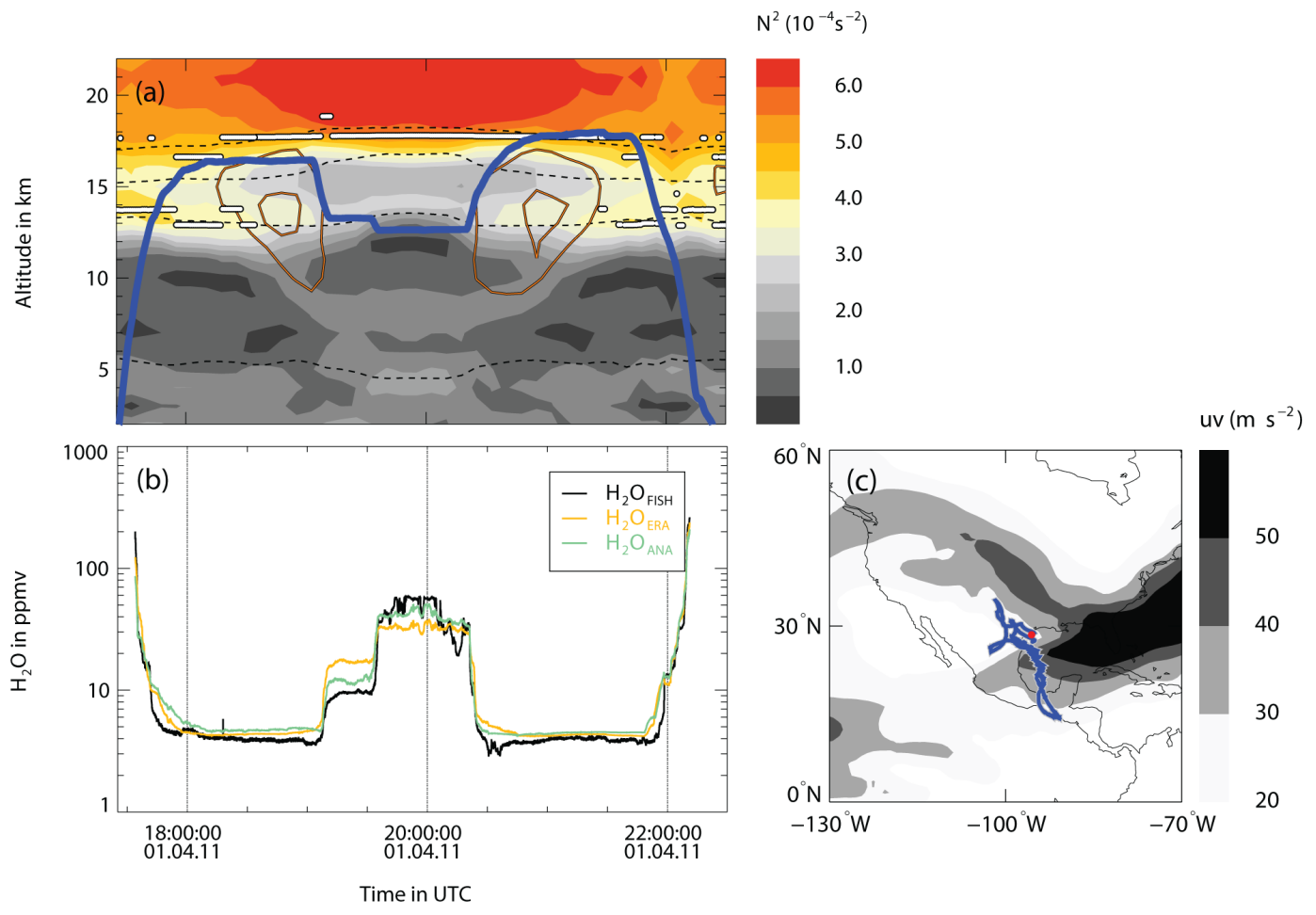

Figure 3. Example flight on 1 April 2011 during the MACPEX campaign over the US between 15 and $40^{\circ}$ N. (a) Altitude-time projection of ERA-Interim static stability (colored contours) along the flight path (blue solid line). Isentropes (320, 350, 380, 410 K) as black dashed lines, zonal wind speed as orange lines $\left(30\right.$ and $\left.40 \mathrm{~m} \mathrm{~s}^{-1}\right)$ and thermal tropopause as a white line. (b) Water vapor mixing ratio in ppmv measured by FISH $\left(\mathrm{H}_{2} \mathrm{O}_{\mathrm{FISH}}\right.$, black line) and ECMWF reanalysis $\left(\mathrm{H}_{2} \mathrm{O}_{\text {ERA }}\right.$, orange line $)$ and operational analysis water vapor mixing ratio $\left(\mathrm{H}_{2} \mathrm{O}_{\mathrm{ANA}}\right.$, green line). (c) Latitude-longitude position of the flight path (blue solid line). Start position of the flight (red point) and the horizontal wind speed (gray contours) are highlighted.

$100 \pm 7.3$ ppmv. The ranges where ECMWF data are indiscriminable from the measured data, i.e., $\Delta \mathrm{H}_{2} \mathrm{O}^{\log 2}=0$, are between -0.20 and 0.23 for $\mathrm{H}_{2} \mathrm{O}_{\text {FISH }}=4 \pm 0.24$ ppmv and -0.10 and 0.11 for $\mathrm{H}_{2} \mathrm{O}_{\text {FISH }}=100 \pm 8$ ppmv.

\subsection{An example flight}

Figures 3 and 4 present the methodology of the ratio of water vapor between (re)analysis fields and FISH for an example flight path during the MACPEX2011 campaign. This flight took place on 1 April 2011 over the US between 15 and $40^{\circ} \mathrm{N}$. There are two special characteristics of this flight (see Fig. 3a): (1) a two-time crossing of the subtropical jet stream in the southward direction of the flight (18:0019:00 UTC) and on the return flight in northward direction (20:30-21:30 UTC). (2) The flight also probed air masses in close vicinity of the thermal tropopause at altitudes between 13 and $18 \mathrm{~km}$. Thus, measurements are collected both in the troposphere and stratosphere with different characteristics of the static stability, $\mathrm{H}_{2} \mathrm{O}_{\text {FISH }}$ and the interpolated $\mathrm{H}_{2} \mathrm{O}_{\text {ERA }}$ and $\mathrm{H}_{2} \mathrm{O}_{\text {ANA }}$ along the flight track (Fig. 3b).

For a quantification of these deviations in water vapor mixing ratio between the model and observations the ratio $\Delta \mathrm{H}_{2} \mathrm{O}^{\log 2}$ is shown both for $\mathrm{H}_{2} \mathrm{O}_{\mathrm{ANA}}$ and $\mathrm{H}_{2} \mathrm{O}_{\text {ERA }}$ in Fig. 4a. For this example flight both $\Delta \mathrm{H}_{2} \mathrm{O}_{\text {ANA }}^{\log 2}$ and $\Delta \mathrm{H}_{2} \mathrm{O}_{\text {ERA }}^{\log 2}$ vary between -1 and 1 . Thus, there are regions with ECMWF underestimations where $\mathrm{H}_{2} \mathrm{O}_{\text {FISH }}$ is twice as large as $\mathrm{H}_{2} \mathrm{O}_{\text {ERA }}$, but also overestimations with $\mathrm{H}_{2} \mathrm{O}_{\text {ERA }}$ twice as large as $\mathrm{H}_{2} \mathrm{O}_{\text {FISH. Around }} 70 \%$ of the values are close to $\Delta \mathrm{H}_{2} \mathrm{O}^{\log 2}=0$ and thus represent a nearly perfect relationship. The ascent and descent parts of the flight in the troposphere (before 18:00 UTC and after 21:45 UTC), and the parts in the vicinity of the equatorward side of the subtropical jet stream (19:00-19:30 and 20:15-20:45 UTC), clearly show an enhanced $\Delta \mathrm{H}_{2} \mathrm{O}^{\log 2}$ with a ratio up to 2 . Here, the ECMWF water vapor may be twice as large as the observations. A fairly good agreement with $\Delta \mathrm{H}_{2} \mathrm{O} \approx 0$ is observed in regions where the airplane samples stratospheric air masses, e.g., 18:00-18:30 and 21:00-21:30 UTC. The largest deviations appear in air masses of the middle tropical troposphere at around $12 \mathrm{~km}$, e.g., at 20:00 UTC, when the ECMWF underestimates the observed water vapor content.

The mean water vapor mixing ratio per $\Delta \mathrm{H}_{2} \mathrm{O}^{\log 2}$ bin shows that $\mathrm{H}_{2} \mathrm{O}_{\text {ANA }}$ and $\mathrm{H}_{2} \mathrm{O}_{\text {ERA }}$ overestimate $\mathrm{H}_{2} \mathrm{O}_{\text {FISH }}$ at lower mixing ratios than $10 \mathrm{ppmv}$ and underestimate $\mathrm{H}_{2} \mathrm{O}_{\text {FISH }}$ for higher mixing ratios than $30 \mathrm{ppmv}$ (Fig. 4b, c). When comparing $\mathrm{H}_{2} \mathrm{O}_{\text {ERA }}$ and $\mathrm{H}_{2} \mathrm{O}_{\text {ANA }}$ in more detail 

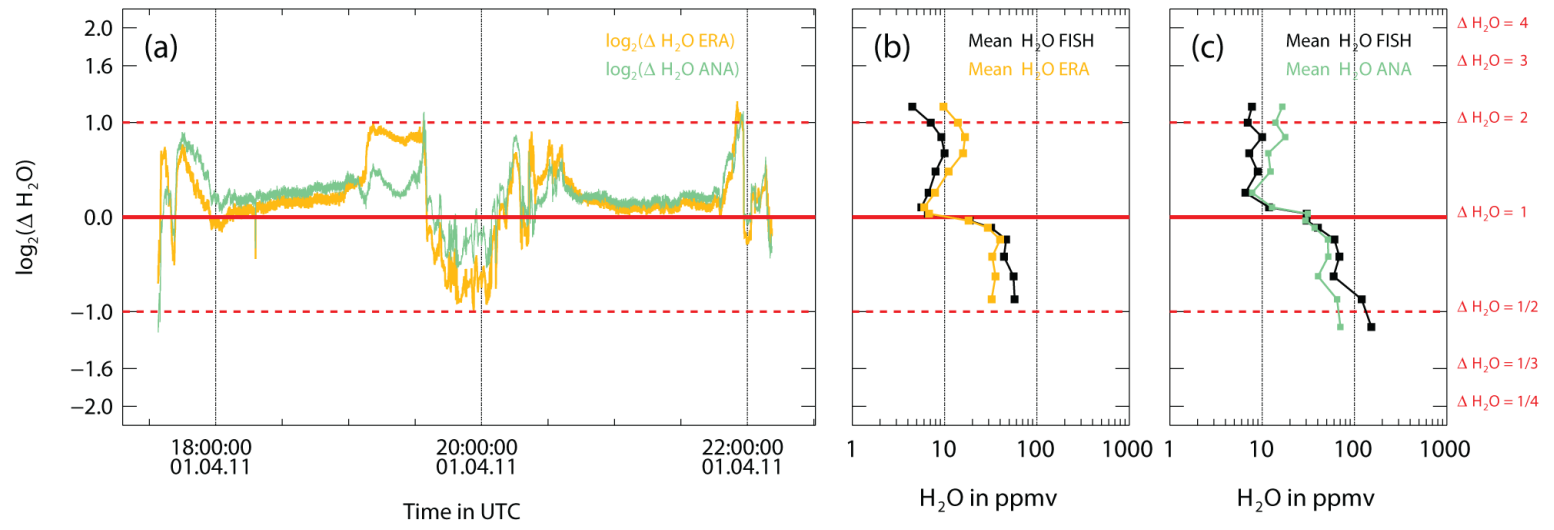

Figure 4. (a) The ratio $\Delta \mathrm{H}_{2} \mathrm{O}^{\log 2}$ for the reanalysis (orange line) and the operational analysis water vapor (green line) for the example MACPEX flight on 1 April 2011 shown in Fig. 3. The red solid line marks a perfect agreement $\left(\Delta \mathrm{H}_{2} \mathrm{O}^{\log 2}=0\right)$. The red dashed lines indicate the limits when the simulations are twice $\left(\Delta \mathrm{H}_{2} \mathrm{O}^{\log 2}=1\right)$ or half $\left(\Delta \mathrm{H}_{2} \mathrm{O}^{\log 2}=-1\right)$ as high as the observations. (b) Mean water vapor mixing ratio per $\Delta \mathrm{H}_{2} \mathrm{O}_{\text {ERA }}^{\log 2}$ bin of $\mathrm{H}_{2} \mathrm{O}_{\mathrm{FISH}}$ (black line) and $\mathrm{H}_{2} \mathrm{O}_{\text {ERA }}$ (orange line). (c) Mean water vapor mixing ratio of $\Delta \mathrm{H} \mathrm{O}_{\mathrm{ANA}}$ bin for $\mathrm{H}_{2} \mathrm{O}_{\mathrm{FISH}}$ (black line) and $\mathrm{H}_{2} \mathrm{O}_{\text {ANA }}$ (green line).

(Fig. 4a), the measurements are better represented by $\mathrm{H}_{2} \mathrm{O}_{\text {ANA }}$ than by $\mathrm{H}_{2} \mathrm{O}_{\text {ERA }}$ in the middle troposphere and close to the jet stream roughly between 19:15 and 20:45 UTC. This may well be explained by an improvement of the ECMWF data assimilation system over 4 years. $\mathrm{H}_{2} \mathrm{O}_{\text {ERA }}$ is based on the IFS release Cy31r2 in 2007, and $\mathrm{H}_{2} \mathrm{O}_{\text {ANA }}$ on Cy36r1 in 2011. However, there are regions in the stratosphere with water vapor mixing ratios lower than 5 ppmv where $\mathrm{H}_{2} \mathrm{O}_{\text {ERA }}$ slightly better represents $\mathrm{H}_{2} \mathrm{O}_{\text {FISH }}$ than $\mathrm{H}_{2} \mathrm{O}_{\text {ANA. }}$.

\section{Water vapor evaluation: ERA-Interim vs. FISH}

Taking all measurements together, around $30 \%$ of the data are very well represented by the model with $\Delta \mathrm{H}_{2} \mathrm{O}_{\text {ERA }}^{\log 2}$ between -0.15 and 0.15 ; i.e., there is a deviation of lower than $10 \%$. The majority of the data, i.e., $57 \%$, are within the $\triangle \mathrm{H}_{2} \mathrm{O}_{\text {ERA }}^{\log 2}$ bins -1 to -0.15 and 0.15 to 1 , and $13 \%$ are connected with a severe under- $\left(\Delta \mathrm{H}_{2} \mathrm{O}_{\text {ERA }}^{\log 2}<-1\right)$ or overestimation $\left(\Delta \mathrm{H}_{2} \mathrm{O}_{\mathrm{ERA}}^{\log 2}>1\right)$. Over- and underestimations are found both in the stratosphere and troposphere, whereas the troposphere is characterized by larger deviations than the stratosphere. This is discussed in more detail in the following sections.

\subsection{Campaign-based analysis}

Since the measurement campaigns represent different geographical and altitude regions (see Fig. 1), the comparison between ERA-Interim and FISH water vapor is first performed for each campaign separately.

Figure 5 (left panels, respectively) shows the frequency distribution of $\Delta \mathrm{H}_{2} \mathrm{O}_{\mathrm{ERA}}^{\log 2}$ for each campaign. The range of
$\Delta \mathrm{H}_{2} \mathrm{O}_{\text {ERA }}^{\log 2}$ is between -3.3 and 3.3, and its bin size is variable to represent reasonable scales as shown Fig. 2. In general, $\Delta \mathrm{H}_{2} \mathrm{O}_{\text {ERA }}^{\log 2}$ values between -2.8 and 2.3 are found; i.e., the model occasionally underestimates the observations by up to a factor of 7 and overestimates them by up to a factor of 5. Dependent on the campaign, around $10-20 \%$ of the data are within a $\Delta \mathrm{H}_{2} \mathrm{O}_{\mathrm{ERA}}^{\log 2}$ range between -0.15 and 0.15 , indicating an almost perfect agreement between the reanalyses and observations. The majority of the data, i.e., around $40-80 \%$, are within the $\Delta \mathrm{H}_{2} \mathrm{O}^{\log 2}$ ranges of -1.0 to -0.15 and 0.15 to 1.0 , indicating a fairly good agreement. Both the mean and median values of $\Delta \mathrm{H}_{2} \mathrm{O}^{\log 2}$ are close to each other at $\Delta \mathrm{H}_{2} \mathrm{O}_{\text {ERA }} \approx 0$ for all campaigns. The range of the mean of $\Delta \mathrm{H}_{2} \mathrm{O}_{\mathrm{ERA}}^{\log 2}$ varies from -0.19 (SPURT2001-2003) to 0.43 (POLARCAT2008). The standard deviation of $\Delta \mathrm{H}_{2} \mathrm{O}_{\mathrm{ERA}}^{\log 2}$ ranges from 0.23 (RECONCILE2010) to 0.99 (SPURT20012003). In particular the SPURT campaigns, which contain data from different seasons and atmospheric situations, have a larger variance around the mean than campaigns like RECONCILE2010, which include data from one single season and a polar-vortex-oriented flight strategy (von Hobe et al., 2013).

Figure 5 (right panels) shows the mean $\mathrm{H}_{2} \mathrm{O}_{\text {ERA }}$ and $\mathrm{H}_{2} \mathrm{O}_{\text {FISH }}$ per $\Delta \mathrm{H}_{2} \mathrm{O}_{\text {ERA }}^{\log 2}$ bin. The mean mixing ratios corresponding to a nearly perfect agreement with $\Delta \mathrm{H}_{2} \mathrm{O}_{\text {ERA }}^{\log 2}$ between -0.15 and 0.15 range from $7 \mathrm{ppmv}$ (e.g., SCOUT2005, ENVISAT2002-2003, EUPLEX2003, RECONCILE2010) to 300 ppmv (e.g., POLARCAT2008). This indicates that ERA-Interim shows accurate water vapor values for both very dry and much moister conditions. There are campaigns, e.g., TROCCINOX2005, where ERA-Interim significantly underestimates the measurements at water vapor mixing ratios larger than $50 \mathrm{ppmv}$ and overestimates the 

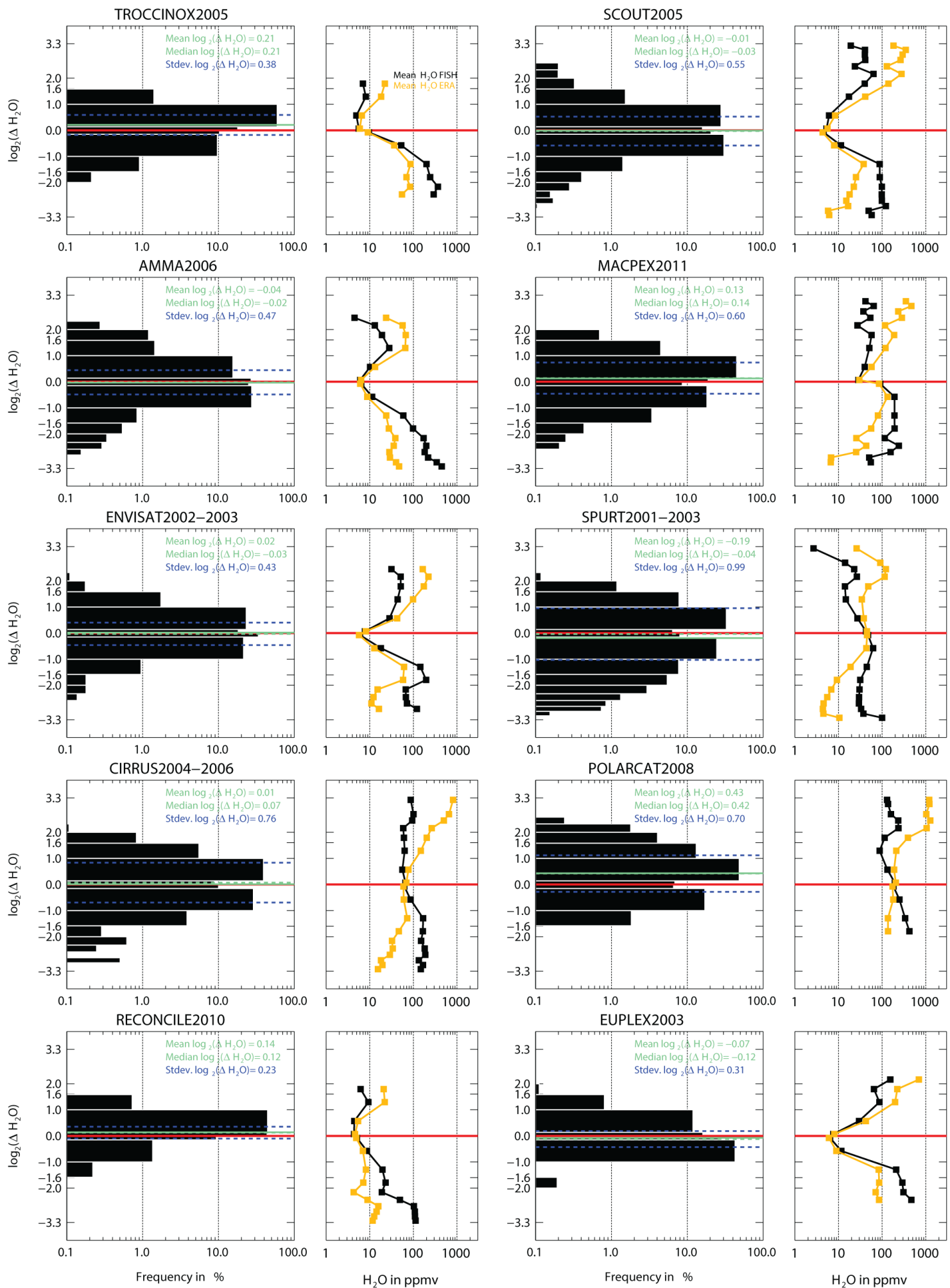

Figure 5. Left panels: frequency distribution of $\Delta \mathrm{H}_{2} \mathrm{O}_{\mathrm{ERA}}^{\log 2}$ separately for each measurement campaign. Bin size of $\Delta \mathrm{H}_{2} \mathrm{O}_{\mathrm{ERA}}^{\log 2}$ is organized according to Fig. 2. Only frequencies larger than $0.1 \%$ are shown. The red solid line marks a perfect agreement $\left(\Delta \mathrm{H}_{2} \mathrm{O}_{\mathrm{ERA}}^{\log 2}=0\right)$. The mean of the distribution (green solid line), the median (green dashed line) and the standard deviation (blue dashed line) are also shown. Right panels: mean water vapor mixing ratio per $\Delta \mathrm{H}_{2} \mathrm{O}_{\text {ERA }}^{\text {log2 }}$ bin for $\mathrm{H}_{2} \mathrm{O}_{\text {FISH }}$ (black line) and $\mathrm{H}_{2} \mathrm{O}_{\text {ERA }}$ (orange line). 
measurements for mixing ratios lower than 50 ppmv. A similar relation for different water vapor values is shown for AMMA2006 also in the tropics and RECONCILE2010 in polar regions. Other campaigns, e.g., ENVISAT2002-2003 and EUPLEX2003, do not show this relationship, and ERAInterim over- and underestimates measurements larger than 50 ppmv.

In summary, a fairly good agreement of mixing ratios with $\Delta \mathrm{H}_{2} \mathrm{O}_{\mathrm{ERA}}^{\log 2} \approx 0$ occurs both at low mixing ratios, e.g., at $\mathrm{H}_{2} \mathrm{O} \approx 10$ ppmv for the TROCCINOX2005 campaign, but also at high mixing ratios, e.g., $\mathrm{H}_{2} \mathrm{O} \approx 300$ ppmv for the POLARCAT2008 campaign. Based on this evaluation of individual measurement campaigns, there is generally an increasing underestimation towards higher FISH mixing ratios and an increasing underestimation towards lower mixing ratios. To gain insight into exactly in which regions of the UTLS over- and underestimations occur, i.e., in the troposphere or in the stratosphere, the data of all campaigns are now analyzed relative to the positions of the tropopause and uppertropospheric jet streams.

\subsection{Tropopause-based analysis in three atmospheric domains}

Following Kunz et al. (2013) the measurement locations are divided into three atmospheric domains with respect to the height of the thermal tropopause $\left(\mathrm{TP}_{\mathrm{H}}\right)$. In the climatological mean, the tropics are characterized by a thermal tropopause height above $14 \mathrm{~km}$, whereas in the extratropics tropopause heights are usually lower than $12 \mathrm{~km}$. Consequently, the tropical and the extratropical domains are separated by the subtropical jet stream characterized by an intermediate tropopause height between 12 and $14 \mathrm{~km}$. The FISHbased climatology is therefore analyzed with respect to the three atmospheric domains:

- tropical measurements (TROP): $\mathrm{TP}_{\mathrm{H}}>14 \mathrm{~km}$;

- subtropical measurements (SUBTROP): $12 \mathrm{~km} \leq \mathrm{TP}_{\mathrm{H}} \leq 14 \mathrm{~km}$;

- extratropical measurements (EXTROP): $\mathrm{TP}_{\mathrm{H}}<12 \mathrm{~km}$.

The separation of the FISH-based water vapor climatology according to these three domains attributes $26 \%$ of data to the tropical, $17 \%$ to the subtropical, and $57 \%$ to the extratropical domain. The proposed selection allows a detailed look at $\Delta \mathrm{H}_{2} \mathrm{O}_{\mathrm{ERA}}^{\log 2}$ for tropical and extratropical measurement locations without mixing dynamical processes on the equatorward and poleward side of the subtropical jet stream (see Fig. 1b). In addition, subtropical measurements in the vicinity of the subtropical jet stream are separately considered. For example, the measurements in-between the double tropopauses in the vicinity of the subtropical jet streams during the example MACPEX flight (see Fig. 3b, 18:00 and 21:30 UTC) are characterized by a thermal tropopause of around $13 \mathrm{~km}$ and are consequently assigned to the subtropical domain.

Figure $6 \mathrm{a}, \mathrm{d}$, and g show $\Delta \mathrm{H}_{2} \mathrm{O}_{\mathrm{ERA}}^{\log 2}$ and the counts of measurements for the three atmospheric domains with respect to the distance from the thermal tropopause. The counts are calculated for $1 \mathrm{~km}$ thick layers, and the $\Delta \mathrm{H}_{2} \mathrm{O}_{\text {ERA }}^{\log 2}$ bins are organized as for Fig. 5. Measurements have been made between -10 and $5 \mathrm{~km}$ around the tropopause in the tropical domain, between -6 and $8 \mathrm{~km}$ in the subtropical domain and between -6 and $10 \mathrm{~km}$ in the extratropical domain. Clear measurement frequency maxima are found in the vicinity of the tropopause in the tropical and extratropical domain. There is a second frequency maximum found between 6 and $9 \mathrm{~km}$ above the tropopause in the extratropical domain, which is probably related to polar campaigns (see Fig. 1). The subtropical domain is characterized by a relatively uniform vertical distribution of measurements with no pronounced maximum near the tropopause. These distributions show the representativeness of individual tropopause and $\Delta \mathrm{H}_{2} \mathrm{O}_{\text {ERA }}^{\log 2}$ bins and should be kept in mind when analyzing the key results in the following.

In all three atmospheric domains, over- and underestimations of the measurements are found in the entire UTLS. The measurement frequency peaks near the tropopause are associated with values of $\Delta \mathrm{H}_{2} \mathrm{O}_{\mathrm{ERA}}^{\log 2}$ that range between -1.0 and 1.0. The LS of the tropical domain is characterized by those values of $\Delta \mathrm{H}_{2} \mathrm{O}_{\mathrm{ERA}}^{\log 2}$ on isentropes above $370 \mathrm{~K}$ (Fig. 6a and b). Toward the extratropics, severe over- and underestimations are found in the LS. The subtropical domain is characterized by a $\Delta \mathrm{H}_{2} \mathrm{O}_{\mathrm{ERA}}^{\log 2}$ roughly between -2.0 and 2.0 on isentropes above $350 \mathrm{~K}$ in the LS (Fig. $6 \mathrm{~d}$ and e); the extratropical domain shows even stronger over- and underestimations in the LS; and $\Delta \mathrm{H}_{2} \mathrm{O}_{\text {ERA }}^{\log 2}$ extends between -3.3 and 2.0 on isentropes above $330 \mathrm{~K}$ (Fig. $6 \mathrm{~g}$ and $\mathrm{h}$ ). Thus, the moist bias of the ECMWF model in the LS that is discussed in the literature is stronger in the extratropics than in the tropics. There is also a dry bias of the model in the LS that is of comparable size to the moist bias.

In the tropical domain, the range of $\Delta \mathrm{H}_{2} \mathrm{O}_{\mathrm{ERA}}^{\log 2}$ is lower in the LS than in the UT (Fig. 6a-c). The UT of the tropical domain is characterized by $\Delta \mathrm{H}_{2} \mathrm{O}_{\mathrm{ERA}}^{\log 2}$ values ranging between -3.3 and 2.8; i.e., underestimations with $\mathrm{H}_{2} \mathrm{O}_{\text {ERA }} 10$ times lower than $\mathrm{H}_{2} \mathrm{O}_{\text {FISH }}$ and overestimations with $\mathrm{H}_{2} \mathrm{O}_{\text {ERA }}$ up to 7 times larger than $\mathrm{H}_{2} \mathrm{O}_{\text {FISH }}$ can be found in the tropical UT. The UT of the subtropical and extratropical domains are not characterized by such strong model deviations as in the tropical domain. Here, $\Delta \mathrm{H}_{2} \mathrm{O}_{\text {ERA }}^{\log 2}$ is comparable between the UT and LS (Fig. 6d-i).

Finally, the strongest over- and underestimations with ERA-Interim more than twice as large or more than half as large as the FISH measurements are found in particular in the tropical UT and extratropical LS. Strong underestimations, i.e., $\Delta \mathrm{H}_{2} \mathrm{O}_{\text {ERA }}<-1.0$, in the UT are connected with 

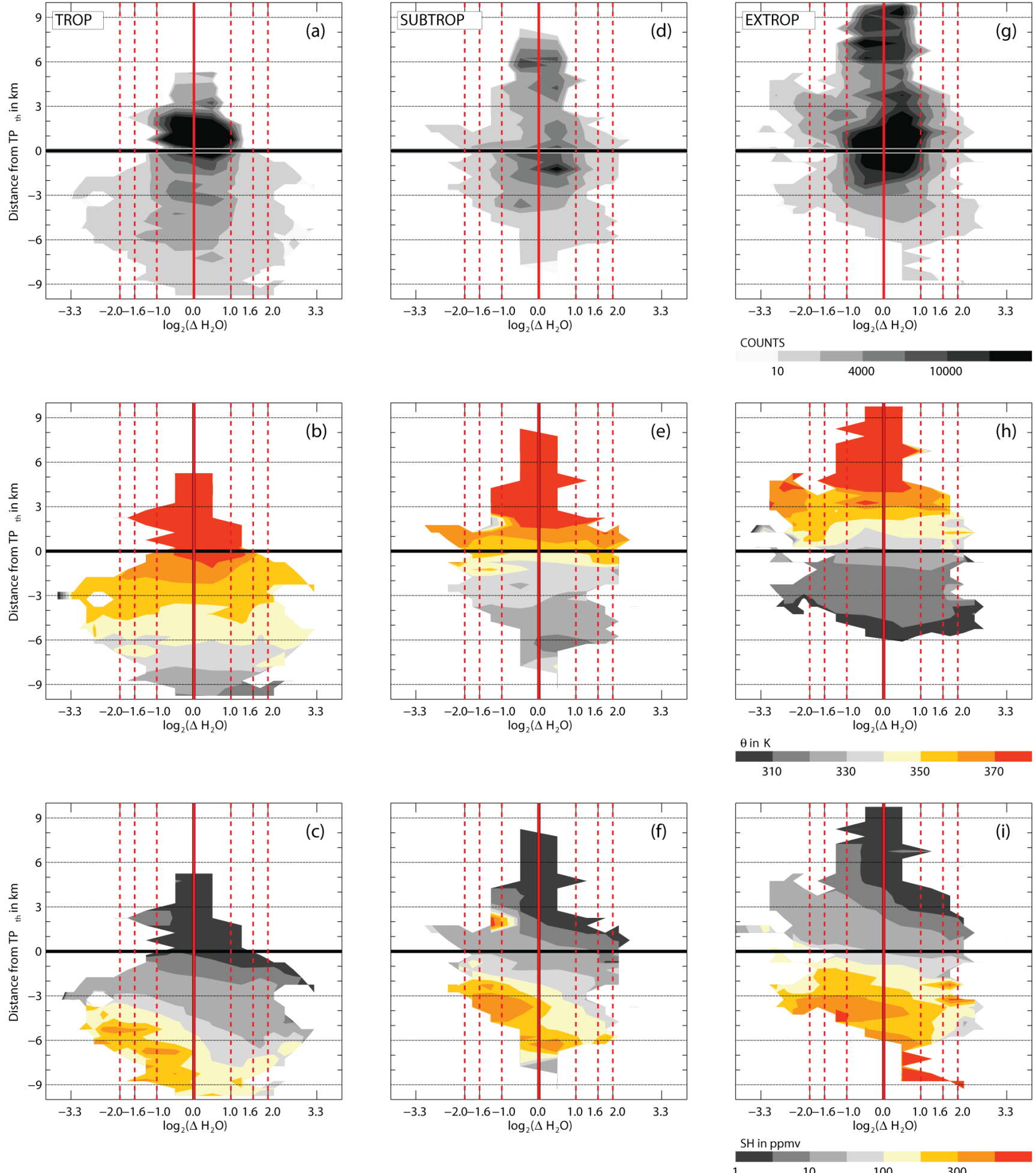

Figure 6. Counts of data, potential temperature and water vapor for all measurement campaigns shown in Fig. 1 plotted in a $\Delta \mathrm{H}_{2} \mathrm{O}_{\text {ERA }}^{\log 2}$ and thermal-tropopause-related coordinate system. The distributions are shown for the tropical $\left(\mathrm{TP}_{\mathrm{H}}>14 \mathrm{~km}\right)(\mathbf{a}, \mathbf{b}$ and $\mathbf{c})$, the subtropical $\left(12 \mathrm{~km} \leq \mathrm{TP}_{\mathrm{H}} \leq 14 \mathrm{~km}\right)(\mathbf{d}, \mathbf{e}$ and $\mathbf{f})$ and the extratropical domain $\left(\mathrm{TP}_{\mathrm{H}}<12 \mathrm{~km}\right)(\mathbf{g}, \mathbf{h}$ and $\mathbf{i})$. The red solid line marks a perfect agreement, i.e, $\Delta \mathrm{H}_{2} \mathrm{O}_{\text {ERA }}^{\log 2}=0$, and the red dashed lines mark a ratio $\Delta \mathrm{H}_{2} \mathrm{O}_{\text {ERA }}^{\log 2}$ between -2 and 2 . Thermal tropopause bin size is $1 \mathrm{~km}$, and $\Delta \mathrm{H}_{2} \mathrm{O}_{\text {ERA }}^{\log 2}$ bins are organized as for Fig. 5 

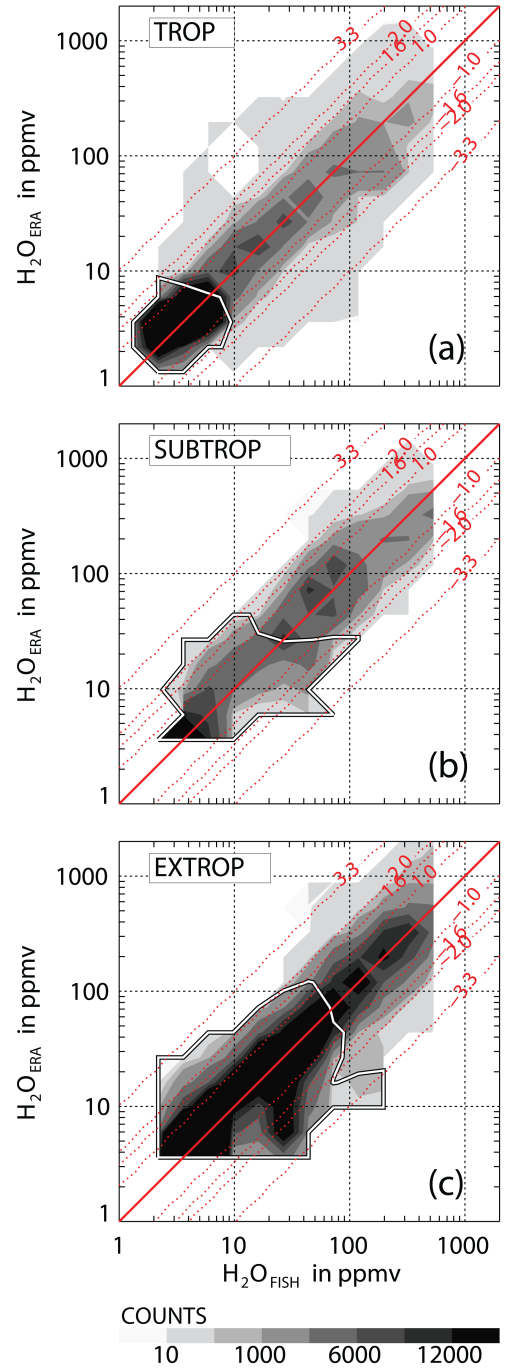

Figure 7. Correlation between $\mathrm{H}_{2} \mathrm{O}_{\text {ERA }}$ and $\mathrm{H}_{2} \mathrm{O}_{\text {FISH }}$ for the tropical (a), subtropical (b) and extratropical domain (c). Filled gray contours represent the counts of data within logarithmic $\mathrm{H}_{2} \mathrm{O}$ bins. Red lines mark selected $\Delta \mathrm{H}_{2} \mathrm{O}_{\text {ERA }}^{\log 2}$ ratios, and the white lines surround bins that are representative of the stratosphere.

FISH water vapor mixing ratios $>300 \mathrm{ppmv}$ (Fig. 6c, f and i). Very low FISH water vapor mixing ratios $<10 \mathrm{ppmv}$ in the LS up to $3 \mathrm{~km}$ above the tropopause are overestimated with a $\Delta \mathrm{H}_{2} \mathrm{O}_{\text {ERA }}^{\log 2}$ up to 1.0 in the tropical domain and up to 2.0 in the subtropical and extratropical domains.

Thus, over- and underestimations are found both in the UT and LS with rather comparable strength in terms of dry and moist bias. In the tropics the spread of $\Delta \mathrm{H}_{2} \mathrm{O}_{\text {ERA }}^{\log 2}$ increases with increasing water vapor mixing ratio from the LS toward the UT (Fig. 6c). This is also reflected by the correlation between $\mathrm{H}_{2} \mathrm{O}_{\text {ERA }}$ and $\mathrm{H}_{2} \mathrm{O}_{\text {FISH }}$ (Fig. 7a). Thus, the correlation between $\mathrm{H}_{2} \mathrm{O}_{\text {ERA }}$ and $\mathrm{H}_{2} \mathrm{O}_{\text {FISH }}$ gets weaker toward higher water vapor mixing ratios in the tropical domain. This relationship is weaker in the subtropical and extratropical do-
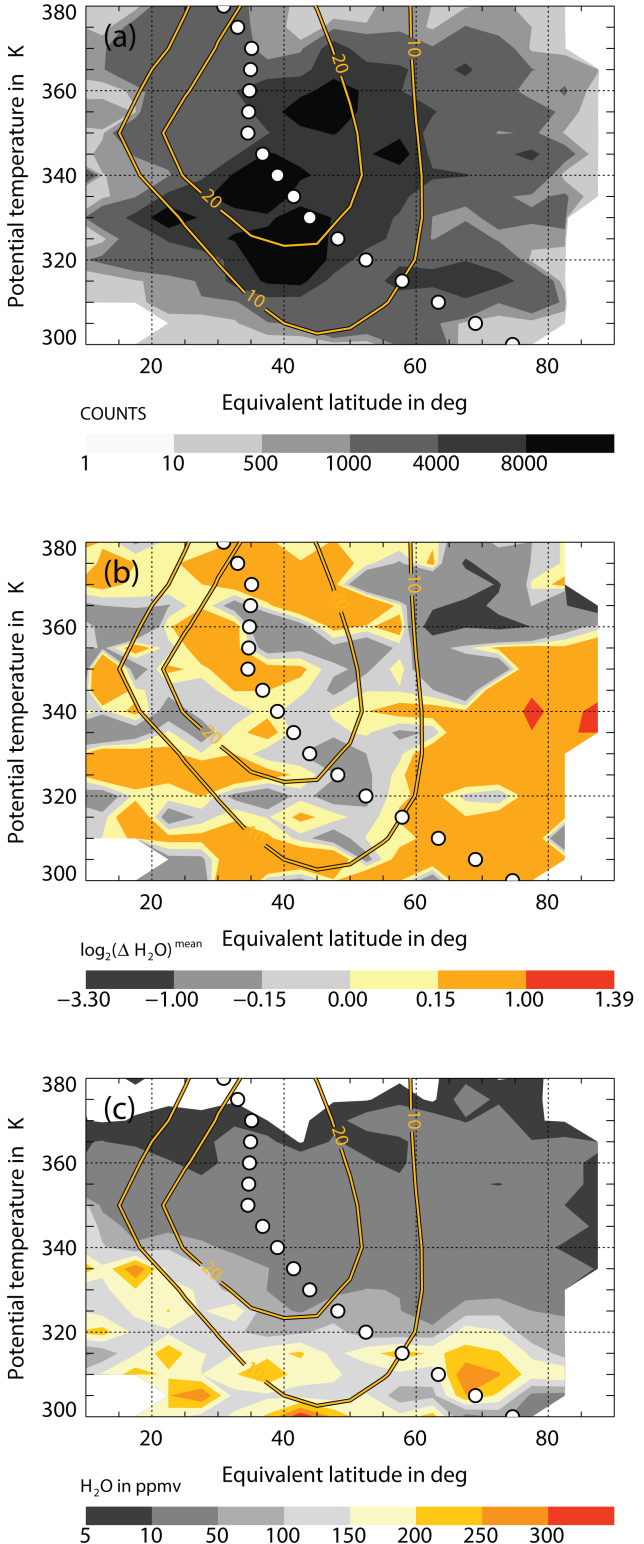

Figure 8. Counts of data (a), mean $\Delta \mathrm{H}_{2} \mathrm{O}_{\text {ERA }}^{\log 2}$ (b) and mean $\mathrm{H}_{2} \mathrm{O}_{\mathrm{FISH}}$ (c) based on all Northern Hemisphere measurement campaigns (TROCCINOX and SCOUT are excluded) per $5 \mathrm{~K}$ potential temperature and $5^{\circ}$ equivalent latitude bin. The equivalent latitude position of the dynamic tropopause (white circles) is shown on each isentrope as the mean over all measurement days. Zonal mean zonal wind speed on all measurement days is represented by orange contours.

mains (Fig. $7 b$ and c), where $\Delta \mathrm{H}_{2} \mathrm{O}_{\mathrm{ERA}}^{\log 2}$ is of rather comparable size in the UT and LS.

\subsection{Equivalent-latitude-based analysis on isentropes}

The potential temperature and equivalent latitude coordinates provide an isentropic view on the relation between $\mathrm{H}_{2} \mathrm{O}_{\text {ERA }}$ and $\mathrm{H}_{2} \mathrm{O}_{\text {FISH }}$ (Fig. 8). Here, the isentropic concept 

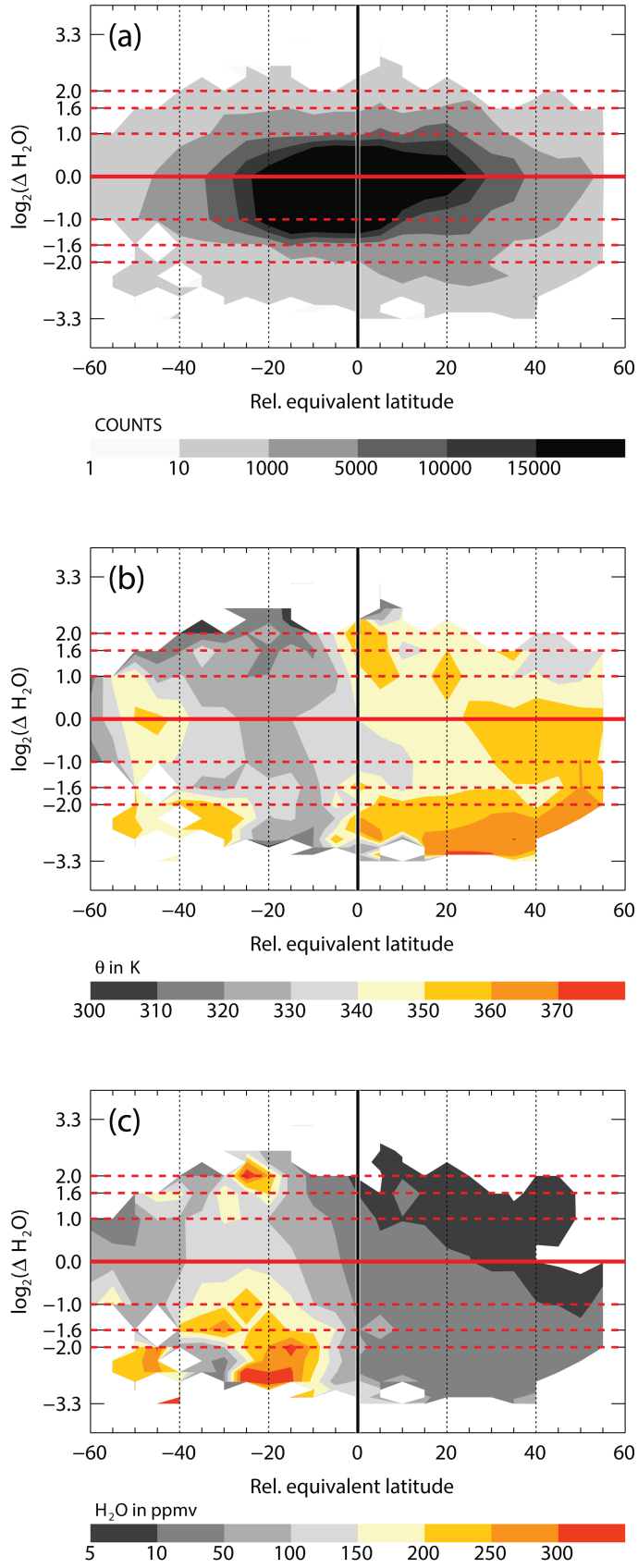

Figure 9. Counts of data (a), mean potential temperature (b) and mean $\mathrm{H}_{2} \mathrm{O}_{\mathrm{FISH}}$ (c) of all Northern Hemisphere measurement campaigns (TROCCINOX and SCOUT are excluded) plotted as averages per logarithmic $\Delta \mathrm{H}_{2} \mathrm{O}_{\text {ERA }}^{\log 2}$ and $5^{\circ}$ relative equivalent latitude difference bin with respect to the dynamic tropopause (see white circles in Fig. 8).

of equivalent latitude is used to reduce the effects of reversible transport processes such as tropospheric and stratospheric intrusions connected to the dynamic tropopause in the UTLS (Olsen et al., 2010; Pan et al., 2012). The location of the dynamic tropopause based on the maximum isentropic PV gradients is determined according to Kunz et al. (2011a) (see also Sect. 2.2). This PV-gradient-based tropopause well represents the dynamical and chemical discontinuity between the UT and LS (Kunz et al., 2011a, b). Thus, it is located in the vicinity of the core of the subtropical jet stream on isentropes between 320 and $380 \mathrm{~K}$ (Fig. 8a). Figure 9 presents the quasi-horizontal distance of the FISH measurements at equivalent latitude from the PV-gradientbased tropopause on isentropes between 300 and $380 \mathrm{~K}$. Negative values represent measurements on the equatorward side of the jet stream in the troposphere and positive values on the poleward side of the jet stream in the stratosphere; see also Kunz et al. (2011b) and Pan et al. (2012).

The highest frequency of FISH measurements can be found near the location of the jet stream and the dynamic tropopause, in particular on isentropes between 310 and $370 \mathrm{~K}$ (Fig. 8a). This area of high sampling frequency of $\mathrm{H}_{2} \mathrm{O}_{\text {FISH }}$ extends at equivalent latitudes up to $\pm 20^{\circ}$ around the dynamic tropopause and is related to a $\Delta \mathrm{H}_{2} \mathrm{O}_{\text {ERA }}^{\log 2}$ between -1.0 and 1.0 (Fig. $8 b$ and Fig. 9a).

In line with previous results, over- and underestimations in the UTLS are found on middle-world isentropes both poleward and equatorward of the subtropical jet stream. In general, the mean $\Delta \mathrm{H}_{2} \mathrm{O}_{\text {ERA }}^{\log 2}$ per potential temperature and equivalent latitude bin shows overestimations, with $\mathrm{H}_{2} \mathrm{O}_{\text {ERA }}$ 3 times larger than $\mathrm{H}_{2} \mathrm{O}_{\text {FISH }}$ and underestimations up to 10 times larger, corresponding to a mean $\Delta \mathrm{H}_{2} \mathrm{O}_{\mathrm{ERA}}^{\log 2}$ varying between -3.3 and 1.6 (Fig. 8b). Severe underestimations with a mean $\Delta \mathrm{H}_{2} \mathrm{O}_{\text {ERA }}^{\log 2}$ between -3.3 and -1.0 can be found in the LS on isentropes above $360 \mathrm{~K}$ at equivalent latitudes poleward of $60^{\circ} \mathrm{N}$. The strongest overestimations with a mean mean $\Delta \mathrm{H}_{2} \mathrm{O}_{\text {ERA }}^{\log 2}$ up to 1.6 are also found in the LS poleward of the subtropical jet stream on the $340 \mathrm{~K}$ isentrope. Both areas are characterized by a mean $\mathrm{H}_{2} \mathrm{O}_{\text {FISH }}$ between 10 and 50 ppmv (Fig. 8c).

On the isentropes between 320 and $340 \mathrm{~K}$, there are two areas in the UT around $20^{\circ}$ southward of the dynamic tropopause that are connected with a mean $\mathrm{H}_{2} \mathrm{O}_{\mathrm{FISH}}$ higher than 300 ppmv (Fig. 9c). One of these areas of high $\mathrm{H}_{2} \mathrm{O}_{\text {FISH }}$ in the UT is overestimated and the other one is underestimated by the model (Fig. 9b). Hereby, the underestimation with $\Delta \mathrm{H}_{2} \mathrm{O}_{\mathrm{ERA}}^{\log 2}$ up to -3.3 is stronger than the overestimation up to 2.0. In contrast, a mean $\mathrm{H}_{2} \mathrm{O}_{\text {FISH }}$ of lower than $10 \mathrm{ppmv}$ in the LS up to $50^{\circ}$ northward of the dynamic tropopause is largely overestimated by ERA-Interim, with $\Delta \mathrm{H}_{2} \mathrm{O}_{\text {ERA }}^{\log 2}$ up to 2.0 (Fig. 9c).

\section{Water vapor evaluation: operational analyses vs. FISH}

Using the FISH-based water vapor climatology, the temporal development of the quality of the ECMWF operational analyses in terms of water vapor in the UTLS is analyzed 

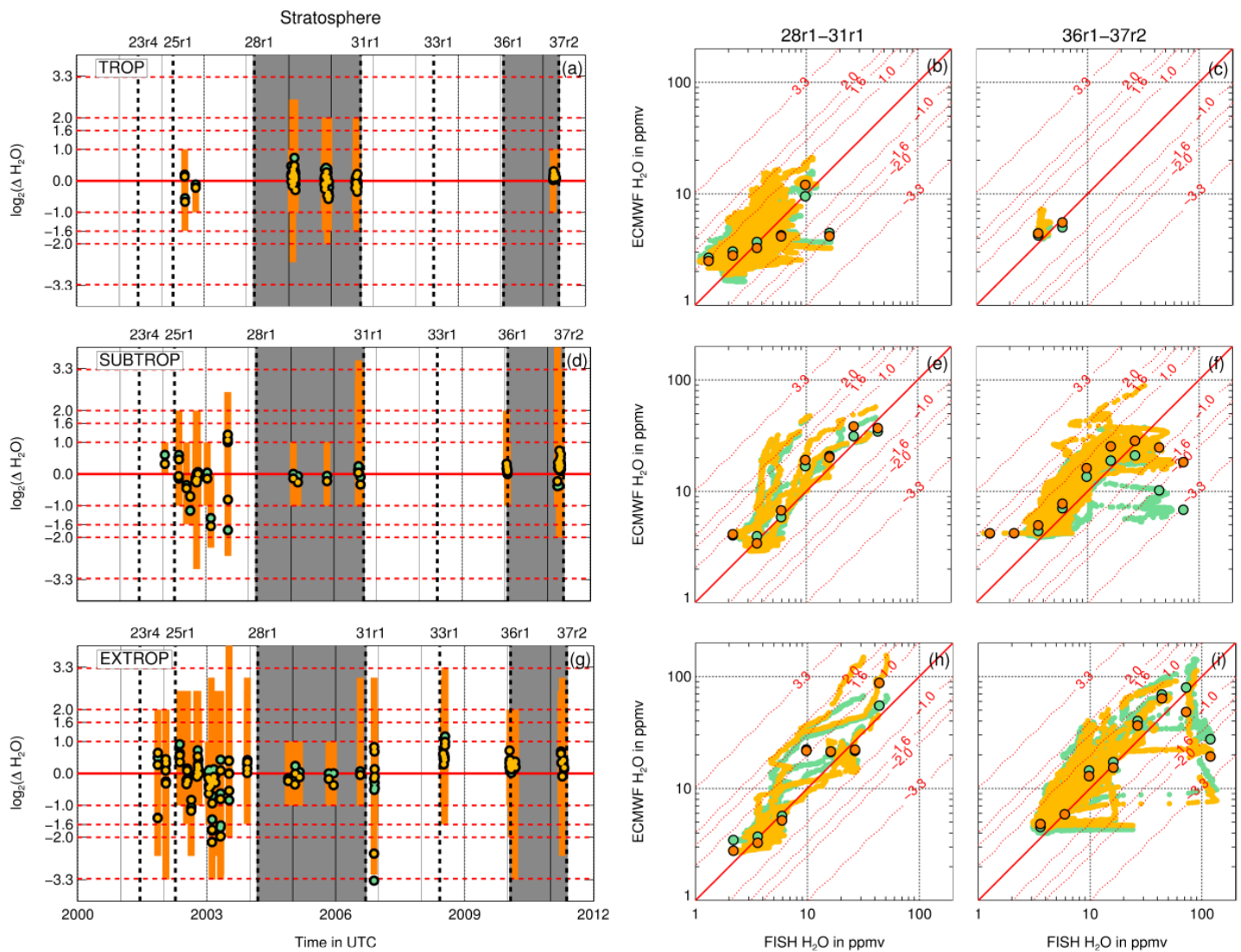

Figure 10. Left panels: daily mean $\Delta \mathrm{H}_{2} \mathrm{O}^{\log 2}$ of operational analysis water vapor mixing ratio $\left(\mathrm{H}_{2} \mathrm{O}_{\text {ANA }}\right.$, black-orange dots) over the time for stratospheric measurements in the tropical (a), subtropical (d) and extratropical domain (g). The range between the minimum and maximum value of $\Delta \mathrm{H}_{2} \mathrm{O}_{\text {ANA }}^{\log 2}$ on each day is marked by the orange vertical bars, and the daily mean $\Delta \mathrm{H}_{2} \mathrm{O}_{\text {ERA }}^{\log 2}$ by the black-green dots. Dashed red lines indicate $\Delta \mathrm{H}_{2} \mathrm{O}^{\log 2}$ between -3.32 and 3.32; black dashed lines indicate the dates when selected IFS cycles became operational. Right panels: correlation of $\mathrm{H}_{2} \mathrm{O}_{\mathrm{FISH}}$ with $\mathrm{H}_{2} \mathrm{O}_{\text {ANA }}$ (orange) and with $\mathrm{H}_{2} \mathrm{O}_{\text {ERA }}$ (green) for two IFS cycle time periods (gray shadings, left panels). The first period, i.e., IFS cycles 28r1-31r1, includes measurements from 9 March 2004 to 12 September 2006 (b, e and h), and the second period, i.e., IFS cycles 36r1-37r2, measurements from 26 January 2010 to 18 May 2011 (c, f and i). Means per $\mathrm{H}_{2} \mathrm{O}_{\mathrm{FISH}}$ bin are shown by larger dots outlined in black.

for the three atmospheric domains. This is done separately for measurements in the stratosphere above the thermal tropopause (Fig. 10) and in the troposphere below the thermal tropopause (Fig. 11). Since different IFS cycles became operational during the 11 years from 2001 to 2011, the daily mean ratio between the operational analysis and FISH water vapor, $\Delta \mathrm{H}_{2} \mathrm{O}_{\mathrm{ANA}}^{\log 2}$, is presented. In addition, the range between the maximum and minimum $\Delta \mathrm{H}_{2} \mathrm{O}_{\mathrm{ANA}}^{\log 2}$ is presented for each single measurement day. For comparison, the daily mean $\Delta \mathrm{H}_{2} \mathrm{O}_{\mathrm{ERA}}^{\log 2}$ is also discussed, which represents the IFS cycle $31 \mathrm{r} 2$, taken for operational forecasting from 12 December 2006 until 5 June 2007.

Over the entire period between 2001 and 2011 the daily mean $\Delta \mathrm{H}_{2} \mathrm{O}_{\mathrm{ANA}}^{\log 2}$ varies between -1.0 and 1.0 within the stratosphere of the tropical domain (Fig. 10a). The daily mean $\Delta \mathrm{H}_{2} \mathrm{O}_{\text {ANA }}^{\log 2}$ varies stronger in the LS of the subtropical and extratropical domains (Fig. 10d and g). In particu- lar, from 2001 to the end of 2003 the daily mean $\Delta \mathrm{H}_{2} \mathrm{O}_{\text {ANA }}^{\log 2}$ varies between -2.0 and 1.0 in the extratropical domain; i.e., the model more strongly underestimates than overestimates most of the measurements. During this time period, observations are mainly from the SPURT campaign in different seasons, which may likely have an influence on the variability of the daily mean $\Delta \mathrm{H}_{2} \mathrm{O}_{\mathrm{ANA}}^{\log 2}$ from 2001 to 2003. Comparing the daily mean $\Delta \mathrm{H}_{2} \mathrm{O}_{\text {ANA }}^{\log 2}$ between the time periods before 2004 and after 2009 shows that $\Delta \mathrm{H}_{2} \mathrm{O}_{\text {ANA }}^{\log 2}$ yields a value close to the perfect agreement $\Delta \mathrm{H}_{2} \mathrm{O} \approx 0$ more often in the later period, in particular in the tropical LS (Fig. 10a).

Figure 10 (middle and right column) shows the correlation of $\mathrm{H}_{2} \mathrm{O}_{\text {FISH }}$ with $\mathrm{H}_{2} \mathrm{O}_{\text {ANA }}$ and with $\mathrm{H}_{2} \mathrm{O}_{\text {ERA }}$ for two selected time periods with IFS cycles 28r1-31r1 (9 March 2004 to 12 September 2006) and IFS cycles 36r1-37r2 (26 January 2010 to 18 May 2011). There is the tendency that strong overestimations with $\Delta \mathrm{H}_{2} \mathrm{O}_{\text {ANA }}^{\log 2}>1.00$ are related to $\mathrm{H}_{2} \mathrm{O}_{\text {FISH }}$ of 

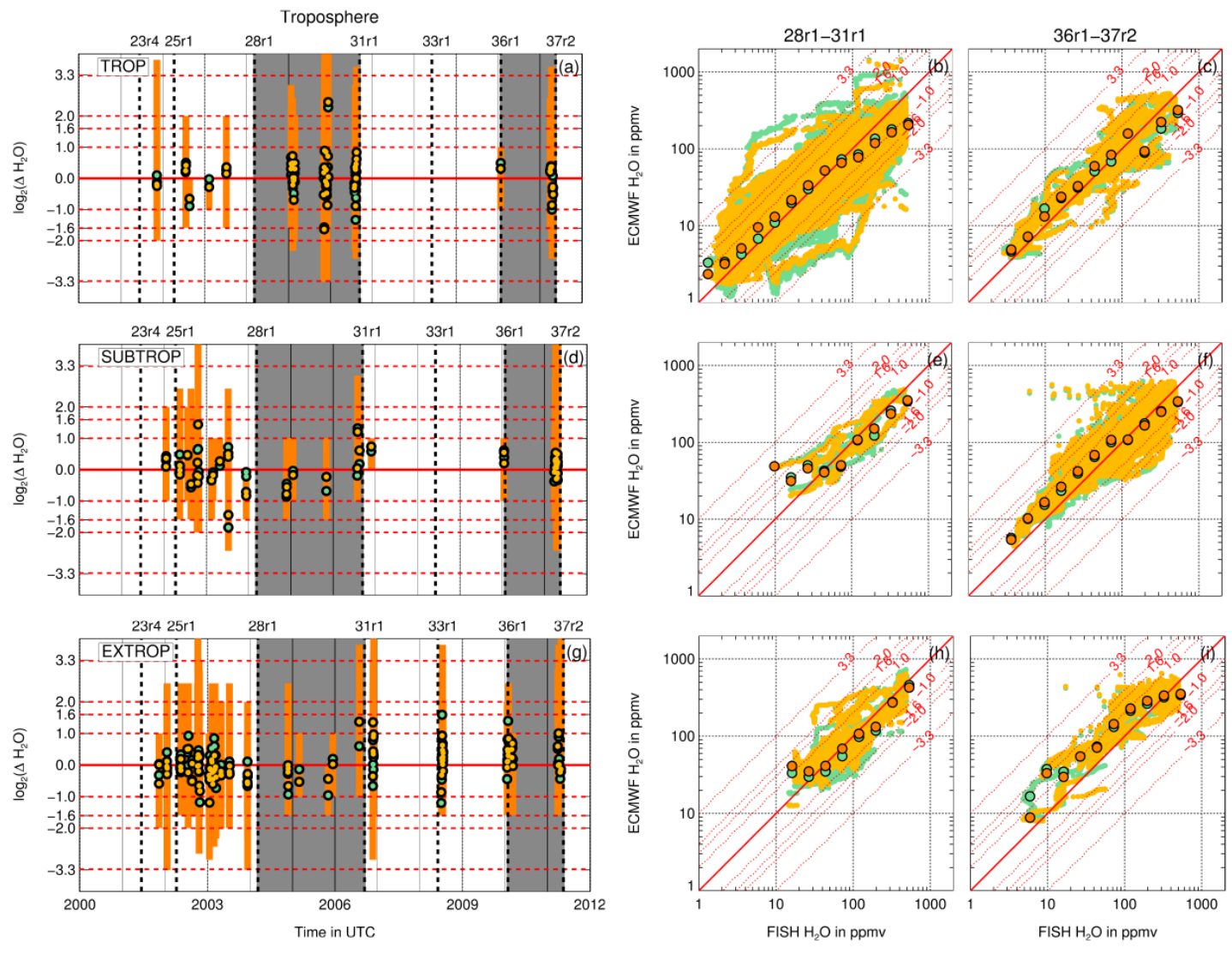

Figure 11. As Fig. 10 but for tropospheric measurements in the three different atmospheric domains.

lower than $5 \mathrm{ppmv}$. This is observed for IFS cycles 28r 1-31r1 and 36r1-37r2, e.g., in the subtropical domain (e.g., Fig. 10, middle row). Thus, the tendency of the model to overestimate low mixing ratios remains for both IFS cycles. In contrast, underestimations with a $\Delta \mathrm{H}_{2} \mathrm{O}_{\mathrm{ANA}}^{\log 2}<-1.00$ are observed for measurements higher than $20 \mathrm{ppmv}$. These strong deviations from the measurements are found in the LS of the subtropical and extratropical domains of IFS cycles 36r1-37r2 (Fig. 10f and i). The LS of the subtropical domain shows that strong overestimations are reduced with a better $\mathrm{H}_{2} \mathrm{O}_{\text {ANA }}$ than $\mathrm{H}_{2} \mathrm{O}_{\text {ERA }}$ for measurements higher than 20 ppmv of IFS cycles 36r1-37r2 (Fig. 10f). These areas of improvement in the operational analysis data can be traced back solely to measurements performed during the MACPEX campaign in 2011, e.g., the MACPEX flight on 11 April 2011 (Fig. 12a and c). A detailed study of this flight shows in the subtropical LS with $\mathrm{H}_{2} \mathrm{O}_{\text {FISH }}>20$ ppmv a clear improvement, with $\mathrm{H}_{2} \mathrm{O}_{\text {ANA }}$ better representing $\mathrm{H}_{2} \mathrm{O}_{\text {FISH }}$ than $\mathrm{H}_{2} \mathrm{O}_{\text {ERA }}$ between 18:25 and 18:35 UTC (Fig. 12b). The measurements during that time period are influenced by the presence of a second thermal tropopause in the LS (Fig. 12a). In addition, these measurements are performed in the vicinity of the thermal tropopause where large gradients of $\mathrm{H}_{2} \mathrm{O}$ appear. This is a further case study besides the example shown in Figs. 3 and
4, which may well show the improvement of the later model cycle compared to the model cycle used for ERA-Interim.

In the troposphere, there is also strong variability of the daily mean $\Delta \mathrm{H}_{2} \mathrm{O}_{\mathrm{ANA}}^{\log 2}$ from 2001 to 2011 both in the tropical and the extratropical domain (Fig. 11, top and bottom row). In the first years after 2007 the range of $\Delta \mathrm{H}_{2} \mathrm{O}_{\text {ANA }}^{\log 2}$ in the extratropical troposphere increases, which may be due to the increased amplitude of tropical and extratropical mesoscale, synoptic and planetary perturbations after the model changes to convection and diffusion parameterization. The increase of $\Delta \mathrm{H}_{2} \mathrm{O}_{\text {ANA }}^{\log 2}$ after 2007 is weaker in the extratropical stratosphere than in the extratropical troposphere (Figs. 10 and 11, bottom row). This may be due to the fact that humidity data are not assimilated above the tropopause. Nevertheless, other changes of data assimilation and model resolution may contribute to the observed increase of $\Delta \mathrm{H}_{2} \mathrm{O}_{\mathrm{ANA}}^{\log 2}$ in the extratropical troposphere after 2007.

When comparing $\Delta \mathrm{H}_{2} \mathrm{O}_{\text {ANA }}^{\log 2}$ between the stratosphere and the troposphere for single years, e.g., 2006, there is the tendency for the tropical troposphere to be characterized by a larger variance of $\Delta \mathrm{H}_{2} \mathrm{O}_{\mathrm{ANA}}^{\log 2}$ than the tropical stratosphere (Figs. 10 and 11, top rows). In contrast, the extratropical troposphere is characterized by a lower variance of $\Delta \mathrm{H}_{2} \mathrm{O}_{\text {ANA }}^{\log 2}$ 


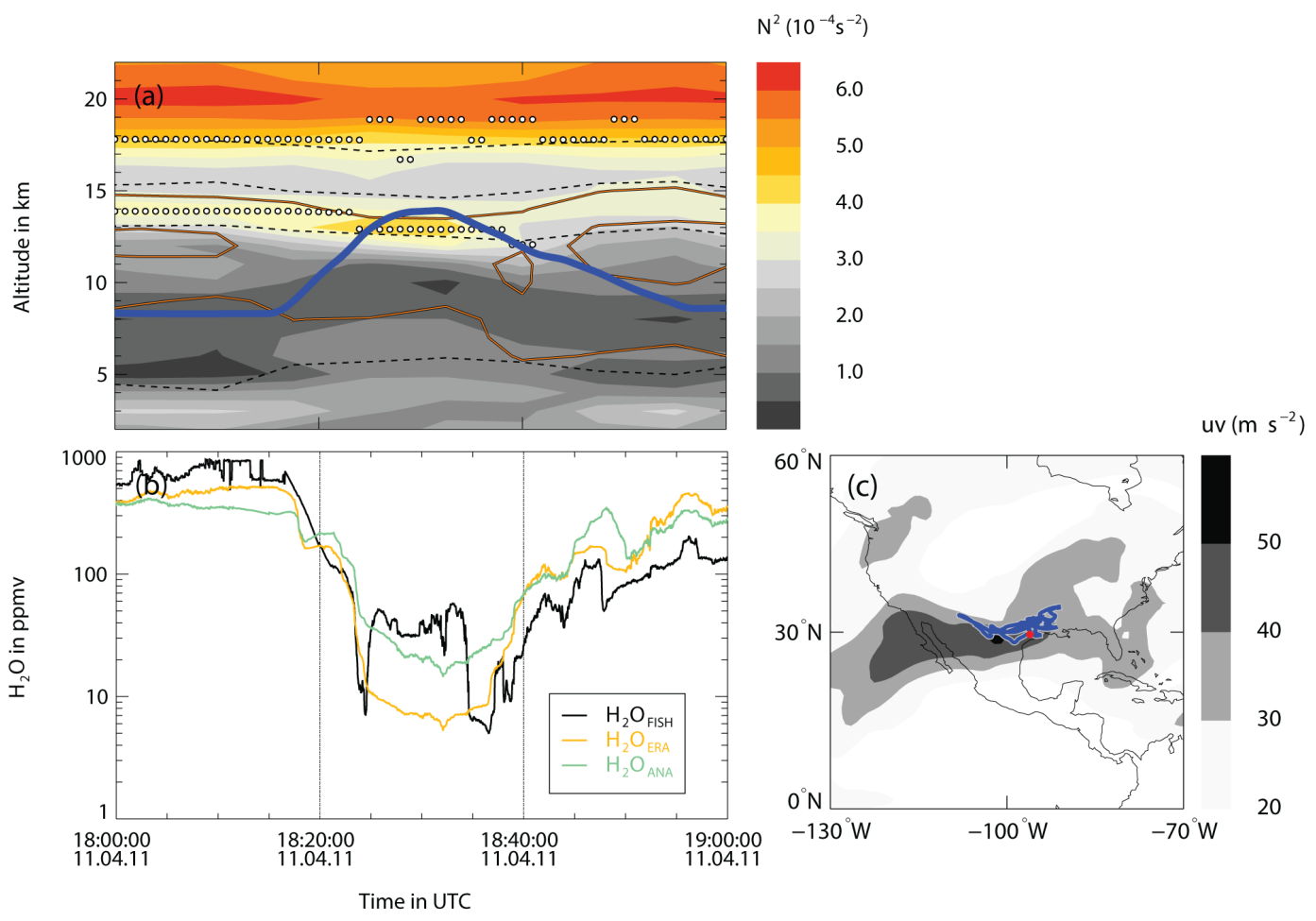

Figure 12. Same as Fig. 3 but for a special flight segment during the MACPEX flight on 11 April 2011.

than the extratropical stratosphere, in particular for the period before 2004 (Figs. 10 and 11, bottom rows). This may well show the difficulty to accurately simulate the influence of tropical tropospheric processes as well as extratropical stratospheric processes on the water vapor distribution. Similar to the stratosphere, the correlation of $\mathrm{H}_{2} \mathrm{O}_{\mathrm{FISH}}$ and $\mathrm{H}_{2} \mathrm{O}_{\text {ANA }}$ in the troposphere shows the tendency of the model to overestimate low and underestimate high mixing ratios (Fig. 11, middle and right columns). The tendencies in over- and underestimations are also observed in the UT of the case study in Fig. 12b during 18:00-18:15 and 18:4519:00 UTC. These time periods indicate no clear improvement of the model cycle since $\mathrm{H}_{2} \mathrm{O}_{\text {FISH }}$ is not better represented by $\mathrm{H}_{2} \mathrm{O}_{\text {ANA }}$ than by $\mathrm{H}_{2} \mathrm{O}_{\text {ERA }}$ for large parts of this flight. Thus, there is no clear improvement of the operational analyses compared to ERA-Interim, indicating that problems remain irrespective of the data assimilation cycle and model resolution.

\section{Summary and discussion}

The latest reanalysis product, the ERA-Interim data set, and the operational analysis product by the ECMWF are evaluated using the global FISH-based water vapor climatology. This climatology represents a valuable data set of highquality airborne water vapor measurements performed during 10 aircraft campaigns from 2001 to 2011 (see Table 1).
The advantage of the FISH-based water vapor climatology is that water vapor is measured with a high accuracy throughout the entire UTLS, a region where satellite data have difficulties to accurately measure trace gas distributions. The FISH-based water vapor climatology allows a detailed evaluation of simulated water vapor fields separately for tropical and extratropical regions.

The UTLS distribution of ECMWF (re)analysis water vapor fields is evaluated using novel analysis methods. Tropical, subtropical and extratropical domains are identified according to their characteristic thermal tropopause heights, i.e., larger than $14 \mathrm{~km}$ and lower than $12 \mathrm{~km}$. The ratio between modeled and observed water vapor mixing ratio is presented in different coordinate systems, i.e., in relative vertical distances with respect to the thermal tropopause and in relative equivalent distances on isentropes with respect to the dynamic tropopause. These different considerations are well suited for the interpretation of the possible influence through diabatic or adiabatic dynamical processes, i.e., crossisentropic and isentropic transport, respectively.

The two main aims of this study are the quantification of the agreement between observed and reanalyzed (ERAInterim) water vapor fields and the investigation of the change of the water vapor representation in ECMWF operational analyses for time periods with different IFS cycles. The main results from this work are as follows: 
- There is generally a good agreement between ERAInterim and FISH water vapor mixing ratio; i.e., $\mathrm{H}_{2} \mathrm{O}_{\text {FISH }}$ and $\mathrm{H}_{2} \mathrm{O}_{\text {ERA }}$, in most parts of the UTLS. The ratio $\Delta \mathrm{H}_{2} \mathrm{O}_{\mathrm{ERA}}^{\log 2}$ is between -1.0 and 1.0 for around $87 \%$ of all observations, i.e., $\mathrm{H}_{2} \mathrm{O}_{\mathrm{ERA}}$ may be half

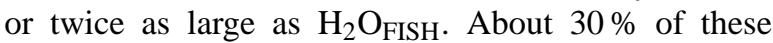
measurements are nearly perfectly represented by the model, with $\Delta \mathrm{H}_{2} \mathrm{O}_{\text {ERA }}^{\log 2}$ between -0.15 and 0.15 ; i.e., positive and negative deviations are lower than $10 \%$. However, ERA-Interim significantly over- and underestimates the FISH measurements for $13 \%$ of the data with $\Delta \mathrm{H}_{2} \mathrm{O}_{\mathrm{ERA}}^{\log 2}$ values of -3.3 or 3.3 ; i.e., the model may be 10 times lower or higher than the observations.

- The tropical LS is well represented by the model; i.e., $\Delta \mathrm{H}_{2} \mathrm{O}_{\text {ERA }}^{\log 2}$ is between -1.0 and 1.0 in the region between the thermal tropopause up to $5 \mathrm{~km}$ above. This result is in particular reflected on isentropes above $370 \mathrm{~K}$ on the equatorward side of the dynamic tropopause. In contrast, the tropical UT is characterized by severe overand underestimations. In the region between $9 \mathrm{~km}$ below the thermal tropopause up to the thermal tropopause $\Delta \mathrm{H}_{2} \mathrm{O}_{\text {ERA }}^{\log 2}$ is observed between -3.3 and 3.3. Here, this result is verified for a large isentropic range between 310 up to $370 \mathrm{~K}$ on the equatorward side of the subtropical jet stream. Convective processes in the entire tropical troposphere may be a reasonable dynamical process responsible for those severe deviations between $\mathrm{H}_{2} \mathrm{O}_{\text {ERA }}$ and $\mathrm{H}_{2} \mathrm{O}_{\text {FISH }}$ over a large range of isentropes.

- In the extratropical LS at altitudes higher than $4 \mathrm{~km}$ above the thermal tropopause the deviations between $\mathrm{H}_{2} \mathrm{O}_{\text {ERA }}$ and $\mathrm{H}_{2} \mathrm{O}_{\text {FISH }}$ are similar to the tropical LS; i.e., $\Delta \mathrm{H}_{2} \mathrm{O}_{\mathrm{ERA}}^{\log 2}$ varies between -1.0 and 1.0. In the entire region $\pm 4 \mathrm{~km}$ around the thermal tropopause the values of $\Delta \mathrm{H}_{2} \mathrm{O}_{\text {ERA }}^{\log 2}$ vary between -3.3 and 2.0; i.e., $\mathrm{H}_{2} \mathrm{O}_{\text {ERA }}$ may be 10 times lower or 4 times larger than $\mathrm{H}_{2} \mathrm{O}_{\text {FISH }}$ near the extratropical tropopause. Dynamical processes playing a role in the vicinity of the thermal tropopause as isentropic exchange processes between the UT and LS may favor these large model deviations in the extratropical UTLS.

- There is the tendency toward an overestimation of low water vapor mixing ratios and an underestimation of high water vapor mixing ratios. In particular, $\mathrm{H}_{2} \mathrm{O}_{\mathrm{FISH}}$ of higher than 300 ppmv in the UT on the equatorward side of the subtropical jet stream within the tropics, subtropics and extratropics is connected with a severe underestimation related to a $\Delta \mathrm{H}_{2} \mathrm{O}_{\text {ERA }}^{\log 2}$ up to -3.3 . In contrast, most of the $\mathrm{H}_{2} \mathrm{O}_{\text {FISH }}$ that is lower than $10 \mathrm{ppmv}$ in the LS is overestimated. Here, the overestimation is lower in the tropics $\left(\Delta \mathrm{H}_{2} \mathrm{O}_{\mathrm{ERA}}^{\log 2}\right.$ up to 1.0) than in the subtropics or extratropics $\left(\Delta \mathrm{H}_{2} \mathrm{O}_{\mathrm{ERA}}^{\log 2}\right.$ up to 3.3). Thus, the moist bias in the LS near the tropopause that is discussed in the literature (e.g., Dyroff et al., 2014) is larger in subtropical and extratropical regions than in the tropics. In general, there is also a dry bias of the model in the UTLS that is of comparable size to the moist bias.

- Similar to ERA-Interim, the operational analyses have the tendency to overestimate low water vapor mixing ratios in the LS and underestimate high mixing ratios in the UT. A case study of $\mathrm{H}_{2} \mathrm{O}_{\text {ANA }}$ for a particular MACPEX flight in 2011 shows that the overestimation of water vapor near the flanks of the subtropical jet stream is reduced by a factor of 2 compared with $\mathrm{H}_{2} \mathrm{O}_{\text {ERA }}$ (Fig. 4). Further, in the subtropical LS the underestimation of water vapor is stronger for $\mathrm{H}_{2} \mathrm{O}_{\text {ERA }}$ than for $\mathrm{H}_{2} \mathrm{O}_{\text {ANA }}$. This may well reflect the improvement of the model cycle used in 2011 for $\mathrm{H}_{2} \mathrm{O}_{\mathrm{ANA}}$ that benefits from several relevant changes compared to the model cycle used in 2007 for $\mathrm{H}_{2} \mathrm{O}_{\text {ERA }}$.

- In our study, the tropical troposphere and the extratropical UTLS turn out to be atmospheric regions with challenging dynamics where both ERA-Interim and the operational analyses have significant deviations from the observations. Nevertheless, there is no clear difference between $\mathrm{H}_{2} \mathrm{O}_{\text {ERA }}$ and $\mathrm{H}_{2} \mathrm{O}_{\text {ANA }}$ in the UTLS during the entire period between 2001 and 2011. This suggests that problems remain concerning the data assimilation cycle and model resolution to accurately simulate the influence of atmospheric processes on the UTLS water vapor distribution. In particular, the influence of tropospheric processes is particularly challenging for the assimilation system. These processes include deep convection, cloud microphysics and transport. Additionally, extratropical dynamical processes like mixing, crosstropopause exchange and convective injections into the lower stratosphere (e.g., Schiller et al., 2009; Ravishankara, 2012; Ploeger et al., 2013) may affect the quality of ECMWF (re)analyses water vapor in the extratropical lower stratosphere. Dyroff et al. (2014) indicated an insufficient model resolution of small-scale intrusions of air masses in the UTLS, and an influence of numerical diffusion associated with the advection scheme in the vicinity of sharp humidity gradients at the tropopause may play a role. These issues may also be possible contributors to the model bias in the lower stratosphere; see also Stenke et al. (2008).

The results of this study might be biased because of the different flight strategies of the campaigns included in the FISH-based water vapor climatology. However, this study represents a comprehensive overview of the ECMWF water vapor distribution in the UTLS from the tropics toward the poles and a validation with independent observations. The results of this study are therefore particularly relevant for studies of the UTLS using ERA-Interim water vapor fields. These 
data have been frequently used for climatologies and trend studies over the past 30 years. Furthermore, the assessment of operational analyses of water vapor is valuable information for future developments of the ECMWF model and also as they are sometimes used as input data for numerical modeling of ice clouds. The correct simulation of the onset of ice nucleation and the prediction of ice clouds in the UT, e.g., based on coupled versions of Lagrangian and microphysical models, are particularly dependent on the quality of the input water vapor fields.

Acknowledgements. This analysis has been performed in memory of C. Schiller facilitating the "FISH-based water vapor climatology" as developer and PI of the FISH instrument during his life's work. A. Kunz has been supported by the European Union Seventh Framework Programme (FP7/2007-2013) under grant agreement no. 299666 with the Marie Curie Fellowship "Dynamical processes in the tropopause region and their impact on the distribution of atmospheric trace gases" (PROTRO). Parts of this research were supported by the German Research Foundation (DFG) under contract HALO-SPP 1294/GR 3786 (LASSO). Many thanks to the ECMWF for providing their products. We are also grateful to J.-U. Grooß, M. Krämer and P. Spichtinger for helpful discussions.

Edited by: P. Jöckel

\section{References}

Andersson, E., Bauer, P., Beljaars, A., Chevallier, F., Hólm, E., Janisková, M., Kallberg, P., Kelly, G., Lopez, P., McNally, A., Moreau, E., Simmons, A. J., Thépaut, J.-N., and Tompkins, A. M.: Assimilation and modeling of the atmospheric hydrological cycle in the ECMWF forecasting system, Bull. Amer. Meteor. Soc., 86, 387-402. doi:10.1175/BAMS-86-3-387, 2005.

Bechtold, P., Köhler, M., Jung, T., Doblas-Reyes, F., Leutbecher, M., Rodwell, M. J., Vitart, F., and Balsamo, G.: Advances in simulating atmospheric variability with the ECMWF model: from synoptic to decadal timescales, Q. J. R. Meteorol. Soc., 134, 1337-1351, 2008.

Blom, C. E., Cortesi, U., and Redaelli, G., ENVISAT validation: Introduction to the correlative measurements by the chemistry payload on board the M-55 Geophysica, Proc. of the 16th ESA Symposium on European Rocket and Balloon Programmes and Related Research, St. Gallen, Switzerland, 2-5 June 2003 (ESA SP-530, August 2003).

Cairo, F., Pommereau, J. P., Law, K. S., Schlager, H., Garnier, A., Fierli, F., Ern, M., Streibel, M., Arabas, S., Borrmann, S., Berthelier, J. J., Blom, C., Christensen, T., D’Amato, F., Di Donfrancesco, G., Deshler, T., Diedhiou, A., Durry, G., Engelsen, O., Goutail, F., Harris, N. R. P., Kerstel, E. R. T., Khaykin, S., Konopka, P., Kylling, A., Larsen, N., Lebel, T., Liu, X., MacKenzie, A. R., Nielsen, J., Oulanowski, A., Parker, D. J., Pelon, J., Polcher, J., Pyle, J. A., Ravegnani, F., Rivière, E. D., Robinson, A. D., Röckmann, T., Schiller, C., Simões, F., Stefanutti, L., Stroh, F., Some, L., Siegmund, P., Sitnikov, N., Vernier, J. P., Volk, C. M., Voigt, C., von Hobe, M., Viciani, S., and Yushkov, V.: An introduction to the SCOUT-AMMA stratospheric aircraft, balloons and sondes campaign in West Africa, August 2006: rationale and roadmap, Atmos. Chem. Phys., 10, 2237-2256, doi:10.5194/acp-10-2237-2010, 2010.

Castanheira, J. M., Peevey, T. R., Marques, C. A. F., and Olsen, M. A.: Relationships between Brewer-Dobson circulation, double tropopauses, ozone and stratospheric water vapour, Atmos. Chem. Phys., 12, 10195-10208, doi:10.5194/acp-12-101952012, 2012.

Dee, D. P., Uppala, S. M., Simmons, A. J., Berrisford, P., Poli, P., Kobayashi, S., Andrea, U., Balmaseda, M. A., Balsamo, G., Bauer, P., Bechtold, P., Beljaars, A. C. M., von de Berg, L., Bidlot, J., Bormann, N., Delsol, C., Dragani, R., Fuentes, M., Geer, A. J., Haimberger, L., Healy, S. B., Hersbach, H., Hólm, E. V., Isaksen, L., Kallberg, P., Köhler, M., Matricardi, M., McNally, A. P., Monge-Sanz, B. M., Morcrette, J.-J., Park, B.-K., Peubey, C., de Rosnay, P., Tavolato, C., Thépaut, J.-N., and Vitart, F.: The ERA-Interim reanalysis: configuration and performance of the data assimilation system, Q. J. R. Meteorol. Soc., 137, 553-597, doi:10.1002/qj.828 2011.

Dyroff, C., Zahn, A., Christner, E., Forbes, R. M., Tompkins, A. M., and van Velthoven, P. F. J.: Comparison of ECMWF analysis and forecast humidity data to CARIBIC upper troposphere and lower stratosphere observations, Q. J. R. Meteorol. Soc., doi:10.1002/qj.2400, online first, 2014.

Engel, A., Bönisch, H., Brunner, D., Fischer, H., Franke, H., Günther, G., Gurk, C., Hegglin, M., Hoor, P., Königstedt, R., Krebsbach, M., Maser, R., Parchatka, U., Peter, T., Schell, D., Schiller, C., Schmidt, U., Spelten, N., Szabo, T., Weers, U., Wernli, H., Wetter, T., and Wirth, V.: Highly resolved observations of trace gases in the lowermost stratosphere and upper troposphere from the Spurt project: an overview, Atmos. Chem. Phys., 6, 283-301, doi:10.5194/acp-6-283-2006, 2006.

Flentje, H., Dörnbrack, A., Fix, A., Ehret, G., and Hólm, E.: Evaluation of ECMWF water vapour fields by airborne differential absorption lidar measurements: a case study between Brazil and Europe, Atmos. Chem. Phys., 7, 5033-5042, doi:10.5194/acp-75033-2007, 2007.

Forbes, R., Tompkins, A. M., and Untch, A.: A new prognostic bulk microphysics scheme for the IFS, ECMWF Technical Memoranda No. 649, available at:http://www.ecmwf.int/ (last access: 13 October 2014), 2011.

Forster, P. M. de F. and Shine, K. P.: Radiative forcing and temperature trends from stratospheric ozone changes, J. Geophys. Res., 102, 10841-10855, 1997.

Fueglistaler, S., Dessler, A. E., Dunkerton, T. J., Folkins, I., Fu, Q. and Mote, P. W.: Tropical tropopause layer, Rev. Geophys., 47, RG1004, doi:10.1029/2008RG000267, 2009.

Haynes, P. and Shuckburgh, E.: Effective diffusivity as a diagnostic of atmospheric transport 2. Troposphere and lower stratosphere, J. Geophys. Res., 105, 22795-22810, 2000.

Hólm, E.: Revision of the ECMWF humidity analysis: Construction of a Gaussian control variable, Proceedings of the ECMWF/GEWEX Workshop on Humidity Analysis, 8-11 July 2002, ECMWF Reading, UK, 2002.

Jensen, E. and Pfister, L.: Transport and freeze-drying in the tropical tropopause layer, J. Geophys. Res., 109, D02207, doi:10.1029/2003JD004022, 2004.

Jones, R. L., and Pyle, J. A.: Observations of $\mathrm{CH}_{4}$ and $\mathrm{N}_{2} \mathrm{O}$ by the NIMBUS 7 SAMS: A comparison with in situ data and two- 
dimensional numerical model calculations, J. Geophys. Res., 89 , 3D1644, doi:10.1029/JD089iD04p05263, 1984.

Krämer, M., Schiller, C., Afchine, A., Bauer, R., Gensch, I., Mangold, A., Schlicht, S., Spelten, N., Sitnikov, N., Borrmann, S., de Reus, M., and Spichtinger, P.: Ice supersaturations and cirrus cloud crystal numbers, Atmos. Chem. Phys., 9, 3505-3522, doi:10.5194/acp-9-3505-2009, 2009.

Kunz, A., Schiller, C., Rohrer, F., Smit, H. G. J., Nedelec, P., and Spelten, N.: Statistical analysis of water vapour and ozone in the UT/LS observed during SPURT and MOZAIC, Atmos. Chem. Phys., 8, 6603-6615, doi:10.5194/acp-8-6603-2008, 2008.

Kunz, A., Konopka, P., Müller, R., and Pan, L. L.: Dynamical tropopause based on isentropic potential vorticity gradients, J. Geophys. Res., 116, D01110, doi:10.1029/2010JD014343, 2011a.

Kunz, A., Pan, L. L., Konopka, P., Kinnison, D. E., and Tilmes, S.: Chemical and dynamical discontinuity at the extra-tropical tropopause-based on START08 and WACCM analyses, J. Geophys. Res., 116, D24302, doi:10.1029/2011JD016686, $2011 \mathrm{~b}$.

Kunz, A., Müller, R., Homonnai, V., Jánosi, I. M., Hurst, D., Rap, A., Forster, P. M., Rohrer, F., Spelten, N., and Riese, M.: Extending water vapor trend observations over Boulder into the tropopause region: trend uncertainties and resulting radiative forcing, J. Geophys. Res., 118, 11269-11284, doi:10.1002/jgrd.50831, 2013.

Lamquin, N., Gierens, K., Stubenrauch, C. J., and Chatterjee, R.: Evaluation of upper tropospheric humidity forecasts from ECMWF using AIRS and CALIPSO data, Atmos. Chem. Phys., 9, 1779-1793, doi:10.5194/acp-9-1779-2009, 2009.

Luebke, A. E., Avallone, L. M., Schiller, C., Meyer, J., Rolf, C., and Krämer, M.: Ice water content of Arctic, midlatitude, and tropical cirrus - Part 2: Extension of the database and new statistical analysis, Atmos. Chem. Phys., 13, 6447-6459, doi:10.5194/acp13-6447-2013, 2013.

Luo, Z., Kley, D., Johnson, R. H., and Smit, H.: Ten Years of Measurements of Tropical Upper-Tropospheric Water Vapor by MOZAIC. Part II: Assessing the ECMWF Humidity Analysis, J. Climate, 21, 1449-1466, doi:10.1175/2007JCLI1887.1, 2007.

McKenna, D., S., Konopka, P., Grooß, J., U., Günther, G., and R. Müller: A new Chemical Lagrangian Model of the Stratosphere (CLaMS), 1. Formulation of advection and mixing, J. Geophys. Res., 107, 4309, doi:10.1029/2000JD000114, 2002.

Oikonomou, E. K., and O'Neill, A.: Evaluation of ozone and water vapor fields from the ECMWF reanalysis ERA-40 during 1991-1999 in comparison with UARS satellite and MOZAIC aircraft observations, J. Geophys. Res., 111, D14109, doi:10.1029/2004JD005341, 2006.

Olsen, M. A., Douglas, A. R., Schoeberl, M. R., Rodriguez, J. M., and Yoshida, Y.: Interannual variability of ozone in the winter lower stratosphere and the relationship to lamina and irreversible transport, J. Geophys. Res., 115, D15305, doi:10.1029/2009JD013004, 2010.

Pan, L. L., Randel, W. J., Gary, B. L., Mahoney, M. J., and Hintsa, E. J.: Definition and sharpness of the extratropical tropopause: A trace gas perspective, J. Geophys. Res., 109, D23103, doi:10.1029/2004JD004982, 2004.

Pan, L. L., Kunz, A., Homeyer, C. R., Munchak, L. A., Kinnison, D. E., and Tilmes, S.: Commentary on using equivalent latitude in the upper troposphere and lower stratosphere, Atmos. Chem. Phys., 12, 9187-9199, doi:10.5194/acp-12-9187-2012, 2012.

Ploeger, F., Günther, G., Konopka, P., Fueglistaler, S., Müller, R., Hoppe, C., Kunz, A., Spang, R., Grooß, J.-U., and Riese, M.: Horizontal water vapor transport in the lower stratosphere from subtropics to high latitudes during boreal summer, J. Geophys. Res., 118, 1-17, doi:10.1002/jgrd.50636, 2013.

Ravishankara, A. R.: Water vapor in the lower stratosphere, Science, 337, 809-810, 2012.

Riese, M., Ploeger, F., Rap, A., Vogel, B., Konopka, P., Dameris, M., and Forster, P.: Impact of uncertainties in atmospheric mixing on simulated UTLS composition and related radiative effects, J. Geophys. Res., 117, D16305, doi:10.1029/2012JD017751, 2012.

Röckmann, T., Grooß, J.-U., and Müller, R.: The impact of anthropogenic chlorine emissions, stratospheric ozone change and chemical feedbacks on stratospheric water, Atmos. Chem. Phys., 4, 693-699, doi:10.5194/acp-4-693-2004, 2004.

Rohrer, F. and Berresheim, H.: Strong correlation between levels of tropospheric hydroxyl radicals and solar ultraviolet radiation, Nature, 442, 184-187, 2006

Rohs, S., Schiller, C., Riese, M., Engel, A., Schmidt, U., Wetter, T., Levin, I., Nakazawa, T., and Aoki, S.: Long-term changes of methane and hydrogen in the stratosphere in the period 1978-2003 and their impact on the abundance of stratospheric water vapor, J. Geophys. Res., 111, D14315, doi:10.1029/2005JD006877, 2006.

Schiller, C., Krämer, M., Afchine, A., Spelten, N., and Sitnikov, N.: The ice water content of Arctic, midlatitude and tropical cirrus, J. Geophys. Res., 113, D24208, doi:10.1029/2008JD010342, 2008.

Schiller, C., Grooß, J.-U., Konopka, P., Plöger, F., Silva dos Santos, F. H., and Spelten, N.: Hydration and dehydration at the tropical tropopause, Atmos. Chem. Phys., 9, 9647-9660, doi:10.5194/acp-9-9647-2009, 2009.

Schäfler, A., Dörnbrack, A., Kiemle, C., Rahm, S., and Wirth, M.: Tropospheric water vapor transport as determined from airborne lidar measurements, J. Atmos. Ocean. Techn., 27, 2017-2030, doi:10.1175/2010JTECHA1418.1, 2010.

Solomon, S., Rosenlof, K. H., Portman, R. W., Daniel, J. S., Davis, S. M., Sanford, F. J., and Plattner, G.-K.: Contributions of stratospheric water vapor to decadal changes in the rate of global warming, Science, 327, 1219-1223, 2010.

Stenke, A., Grewe, V., and Ponater, M.: Lagrangian transport of water vapor and cloud water in the ECHAM4 GCM and its impact on the cold bias, Clim. Dyn., 31, 491-506, 2008.

Tilmes, S., Pan, L. L., Hoor, P., Atlas, E., Avery, M. A., Campos, T., Christensen, L. E., Diskin, G. S., Gao, R.-S., Herman, R. L., Hintsa, E. J., Loewenstein, M., Lopez, J., Paige, M. E., Pittman, J. V., Podolske, J. R., Proffitt, M. R., Sachse, G. W., Schiller, C., Schlager, H., Smith, J., Spelten, N., Webster, C., Weinheimer, A., and Zondlo, M. A.: An aircraft-based upper troposphere lower stratosphere $\mathrm{O}_{3}, \mathrm{CO}$, and $\mathrm{H}_{2} \mathrm{O}$ climatology for the Northern Hemisphere, J. Geophys. Res., 115, D14303, doi:10.1029/2009JD012731, 2010.

Tompkins, A. M., Gierens, K., and Rädel, G.: Ice supersaturation in the ECMWF integrated forecast system, Q. J. R. Meteorol. Soc., 133, 53-63, doi:10.1002/qj.14, 2007.

Uppala, S. M., Kållberg, P. W., Simmons, A. J., Andrae, U., Bechtold, V. D. C., Fiorino, M., Gibson, J. K., Haseler, J., Hernandez, A., Kelly, G. A., Li, X., Onogi, K., Saarinen, S., Sokka, N., Al- 
lan, R. P., Andersson, E., Arpe, K., Balmaseda, M. A., Beljaars, A. C. M., Berg, L. V. D., Bidlot, J., Bormann, N., Caires, S., Chevallier, F., Dethof, A., Dragosavac, M., Fisher, M., Fuentes, M., Hagemann, S., Hólm, E., Hoskins, B. J., Isaksen, L., Janssen, P. A. E. M., Jenne, R., Mcnally, A. P., Mahfouf, J.-F., Morcrette, J.-J., Rayner, N. A., Saunders, R. W., Simon, P., Sterl, A., Trenberth, K. E., Untch, A., Vasiljevic, D., Viterbo, P. and Woollen, J. : The ERA-40 reanalysis, Q. J. R. Meteorol. Soc., 131, 29613012, doi:10.1256/qj.04.176, 2006.

Vaughan, G., Schiller, C., MacKenzie, A. R., Bower, K., Peter, T., Schlager, H., Harris, N. R. P., and May, P. T. E.: SCOUTO3/ACTIVE High-altitude aircraft measurements around deep tropical convection, B. Am. Meteorol. Soc., 89, 647-662, 10.1175/BAMS-89-5-647, 2008.

von Hobe, M., Bekki, S., Borrmann, S., Cairo, F., D’Amato, F., Di Donfrancesco, G., Dörnbrack, A., Ebersoldt, A., Ebert, M., Emde, C., Engel, I., Ern, M., Frey, W., Genco, S., Griessbach, S., Grooß, J.-U., Gulde, T., Günther, G., Hösen, E., Hoffmann, L., Homonnai, V., Hoyle, C. R., Isaksen, I. S. A., Jackson, D. R., Jánosi, I. M., Jones, R. L., Kandler, K., Kalicinsky, C., Keil, A., Khaykin, S. M., Khosrawi, F., Kivi, R., Kuttippurath, J., Laube, J. C., Lefèvre, F., Lehmann, R., Ludmann, S., Luo, B. P., Marchand, M., Meyer, J., Mitev, V., Molleker, S., Müller, R., Oelhaf, H., Olschewski, F., Orsolini, Y., Peter, T., Pfeilsticker, K., Piesch, C., Pitts, M. C., Poole, L. R., Pope, F. D., Ravegnani, F., Rex, M., Riese, M., Röckmann, T., Rognerud, B., Roiger, A., Rolf, C., Santee, M. L., Scheibe, M., Schiller, C., Schlager, H., Siciliani de Cumis, M., Sitnikov, N., Søvde, O. A., Spang, R., Spelten, N., Stordal, F., Sumin'ska-Ebersoldt, O., Ulanovski, A., Ungermann, J., Viciani, S., Volk, C. M., vom Scheidt, M., von der Gathen, P., Walker, K., Wegner, T., Weigel, R., Weinbruch, S., Wetzel, G., Wienhold, F. G., Wohltmann, I., Woiwode, W., Young, I. A. K., Yushkov, V., Zobrist, B., and Stroh, F.: Reconciliation of essential process parameters for an enhanced predictability of Arctic stratospheric ozone loss and its climate interactions (RECONCILE): activities and results, Atmos. Chem. Phys., 13, 92339268, doi:10.5194/acp-13-9233-2013, 2013.
World Meteorological Organization, Meteorology - A threedimensional science, WMO Bull, 6, 134-138, 1957.

Zöger, M., Afchine, A., Eicke, N., Gerhards, M.-T., Klein, E., McKenna, D. S., Mörschel, U., Schmidt, U., Tan, V., Tuitjer, F., Woyke, T., and Schiller, C.: Fast in-situ stratospheric hygrometers: A new family of balloon-borne and airborne Lyman $\alpha$ photofragment fluorescence hygrometers, J. Geophys. Res., 104, 1807-1816, 1999. 